\title{
TFRS Açısından Muhasebe Meslek Mensuplarına Yönelik Yapılmış Olan Akademik Çalışmaların Değerlendirilmesi
}

\author{
Fatma AKYÜZ*, Tolga YEŞİL**
}

ÖZ

Çalışma kapsamında muhasebe meslek mensuplarının Türkiye Finansal Raporlama Standartları (TFRS) ve Küçük ve Orta Büyüklükteki İşletmeler İçin Türkiye Finansal Raporlama Standartları (KOBİ TFRS) ile ilgili bilgi düzeylerinin ölçüldüğü makaleler ve konu ile ilgili olarak hazırlanmış lisansüstü tezler incelenmiş olup muhasebe meslek mensuplarının muhasebe standartlarıyla ilgili beklentileri ve bilgi düzeylerin ölçülmesi ile ilgili olarak farklı illerde yapılmış çalışmaların tümünde en önemli ortak sorunun muhasebe meslek mensuplarının standartlarla ilgili bilgi ve sistematik eğitim eksikliği olduğu sonucuna varıldığı görülmüştür. Çalışmada yasal düzenlemeler ile zorunlu hale getirilen muhasebe standartlarının uygulamada fazla karşılık bulamadığı muhasebe meslek mensupları açısından fazladan iş yükü olarak algılandığı ve mesleği bırakma eğilimi gibi olumsuz sonuçlar doğurabileceği sonucuna varılmıştır.

Anahtar Kelimeler: TFRS, Muhasebe Standartları, Muhasebe Meslek Mensuplar1

JEL Sınıflandırması: M41

\section{IFRS of the Accounting Profession in Terms of Evaluation of the Academic Studies that Have Been Made against Members}

\begin{abstract}
Within the scope of the study, the Turkish Financial Reporting Standards (TFRS) and the Turkish Financial Reporting Standards for Small and Medium Enterprises (SME TFRS) and the postgraduate theses prepared in relation to the subject were examined for the accounting profession members and the expectations about the accounting standards of the accounting profession And the level of knowledge, the most important common problem in all of the studies in different illusions was the lack of information and systematic training of the professional accountants about the standards. In the study, it has been concluded that legal standards and accounting standards, which are made compulsory, have negative consequences such as extra work load and tendency to leave the profession in terms of professional members who can not find much in practice.
\end{abstract}

Keywords: IFRS, Accounting Standards, Professional Accountants

JEL Classification: M41

Geliş Tarihi / Received: 17.11.2016 Kabul Tarihi / Accepted: 12.12.2016

\footnotetext{
*Yrd.Doç.Dr., Uşak Üniversitesi, İIBF, İşletme Bölümü, fatma.akcanli@usak.edu.tr

*** Doktora Öğrencisi, Uşak Üniversitesi, SBE, İşletme Anabilim Dal,tolga.yesil@yahoo.com
} 


\section{GİRİş}

İşletmeler mali durumlarını, finansal tablolar aracılığıyla bilgi kullanıcılarına sunmaktadırlar. İşletmelerin uluslararası alanda da sürdürmeleri hazırlamış oldukları finansal tablo ve raporların da uluslararası bilgi kullanıcılarına hitap etmesini gerektirmektir. Ayrıca işletmelerin mali durumlarını finansal tabloları aracılığıyla sektördeki diğer işletmelerle de karşılaştırılabilir hale getirmeleri gerekmektedir.

Türkiye'deki muhasebe standartları ile ilgili gelişmelerin 2002 yılında Avrupa Birliği tarafından, halka açık tüm şirketlerin 2005 yılı mali tablolarında Uluslararası Finansal Raporlama Standartları'na (UFRS) tabi olmalarını gerektiren bir muhasebe düzenlemesini onaylaması ile başladığ̣, 2011 yılında 6102 sayılı Türk Ticaret Kanunu’nun, 2013 yılında Küçük ve Orta Büyüklükte İşletmeler İçin Türkiye Finansal Raporlama Standartları (KOBİ TFRS) yürürlüğe girmesiyle devam ettiği görülmektedir (Apak vd., 2016;183).

Ekonomik, sosyal ve hukuki alanda yapılan ulusal düzenlemeler nedeniyle finansal tablolar ülkeden ülkeye farklılıklar göstermektedir. Türkiye Finansal Raporlama Standartlarının uygulanmasıyla birlikte ülkemizdeki vergi muhasebesinden bilgi muhasebesine dönüşümünü ve işletmelerin finansal tablolarının uluslararası düzeyde uyumlaştırılması da amaçlanmaktadır. Uluslararas1 düzeydeki standartlar, finansal tabloların uluslararası yatırımcinın da yararlanabileceği hale getirilmesini gerekli kılmaktadır. Dolayısıyla, Türkiye'deki işletmelerin uluslararası alandaki faaliyetlerinde kolaylık sağlamak amacıyla Türkiye Finansal Raporlama Standartlarına tüm şirketlerde uygulama zorunluluğu getirilmiştir.

İşletmelerin uygulamakla yükümlü olduğu finansal raporlamada ilkelere dayalı uluslararası anlamda finansal standartlarla birlikte finansal tabloların daha şeffaf olmasında meslek mensuplarına önemli görevler düşmektedir (Hussain vd., 2012;107). Yani standartların uygulanmasında muhasebe meslek mensupları kilit rol oynamaktadır. Türkiye'de bazı illerde meslek mensuplarına yönelik olarak finansal raporlama standartlarıyla ilgili eğitimler verilmiştir. Bu amaçla Türkiye' de iller bazında yapılmış olan çalışmalar literatür taramasında ayrıntılı olarak incelenmiş ve meslek mensuplarının standartlarla ilgili bilgi düzeyleri, beklentileri ve görüşleri doğrultusunda değerlendirmeler yapılmıştır.

\section{TÜRKIYYE FİNANSAL RAPORLAMA STANDARTLARI (TFRS) VE KÜÇÜK VE ORTA BÜYÜKLÜKTE İŞLETMELER IÇİN TÜRKIYE FINANSAL RAPORLAMA STANDARTLARI (KOBİ TFRS)}

Türkiye' de Uluslararası muhasebe standartlarına yönelik uyum çalışmaları amacıyla kurulmuş olan kurumlar, muhasebe meslek mensupları ve devlet arasında önemli bir köprü oluşturmaktadır. 1994 yılında Türkiye Muhasebe Standartları'nın oluşturulması için Türkiye Serbest Muhasebeci Mali Müşavirler ve Yeminli Mali Müşavirler Odaları Birliği (TÜRMOB) tarafından Türkiye Muhasebe ve Denetim Standartları Kurulu (TMUDESK) kurulmuştur. 1999 yılında TMUDESK' e ait görev ve yetkiler Türkiye Muhasebe Standartları Kurulu'na (TMSK) devredilmiş olup 01.11.2010 tarihinde KOBİ TFRS standardını yayınlamıştır. Türkiye'de IFRS ile ilgili uyum süreci için ilk yasal düzenleme 15 Kasım 2003 tarihinde 25290 sayılı Resmi Gazete ile borsada işlem gören şirketlerde uygulanmak üzere yürürlüğe girmiştir. Muhasebe standartları günümüz tarihiyle yetkili olarak Kamu Gözetimi, Muhasebe ve Denetim Standartlar1 Kurumu tarafından yayınlamaktadır (Cengiz, 2014;165; Gökgöz, 2012;244).

IFRS zorunlu hale gelmeden önce Almanya muhasebe standartlarına uyum için gönüllü olarak çalışmalara başlayan ülkelerden birisi olmuştur (Christensen vd., 2015;31). Uluslararası Muhasebe Standartlar1 (IFRS), Uluslararas1 Muhasebe Standartlar1 Kurulu (IASB) tarafindan belirlenmektedir. IASB kurulu bünyesinde farklı milletlerden olan 14 üyenin oluşturduğu 
Uluslararası Finansal Raporları Yorumlama Komitesi (IFRIC) IFRS belirlenmesi aşamasında yetkilidir (http://ifrs.org, Erişim Tarihi:05.10.2016). Uluslararası muhasebe standartlarına uyum çalışmaları, TMSK tarafından 2005 yılında standartlar yayınlayarak uygulamaya geçmiştir. 1 Ocak 2013 tarihi itibariyle, Türk Ticaret Kanunuyla bazı şirketlere muhasebe standartlarını uygulama zorunluluğu getirilmiştir.

Farklı büyüklükteki işletmelerin var olduğu ekonomik sistem içerisinde standartların uygulanmasında oluşabilecek sorun ve olumsuzlukların minimuma indirilmesi uyum sürecinde önem teşkil etmektedir. Bu nedenle Küçük ve Orta Büyüklükteki İşletmeler için International Financial Reporting Standard For Small and Medium-Sized Entities (IFRS For SMEs), Türkçeye çevrilerek Küçük ve Orta Büyüklükte İşletmeler İçin Türkiye Finansal Raporlama Standartları (KOBİ TFRS) oluşturulmuştur (Gönen ve Demir, 2012;164). KOBİ TFRS Bölüm 1(1.1) de bu durum 'KOBİ TFRS' nin, Küçük ve Orta Büyüklükteki İşletmeler (KOBİ) tarafindan kullanılması amaçlanmaktadır" şeklinde belirtilmektedir. Finansal tablolarını KOBİ TFRS ile uyumlu olan işletmelerin bu durumu finansal tablolarının dipnotlarında açıkça belirtmiş olmaları gerekmektedir İşletme tarafindan hazırlanan finansal tablolar, işletme dışındaki finansal tablo kullanıcılarına bilgi sağlamaktadır. Hazırlanan finansal raporlar işletmenin durumu hakkında bilgi sağlamaktadır. Finansal bilginin niteliksel özellikleri aşağıdaki gibi sıralanabilir (KOBİ TFRS, http://kgk.gov.tr, Erişim Tarihi: 05.10.2016):

- İhtiyaca uygun olmas1,

- Gerçeğe uygun şekilde sunumu,

- Karşılaştırılabilir olması,

- Doğrulanabilir olması,

- Zamaninda sunum,

- Anlaşılabilir olması.

Türkiye Finansal Raporlama Standartları, Kamu Gözetimi, Muhasebe ve Denetim Standartları Kurumu tarafindan 2011, 2013, 2014, 2015 ve 2016 yılları itibariyle güncellenerek ilgili tarihteki Resmi Gazete' lerde yürürlüğe sokulmuştur. Yürürlükte olan 2016 TFRS setinde kavramsal çerçeve ve 15 adet Türkiye Finansal Raporlama Standartı bulunmaktadır. Kavramsal çerçevenin kapsadığı konular TFRS 2016 setinde aşağıdaki maddeler halinde yer almaktadır:

- Finansal raporlamanın amac1

- Faydalı finansal bilginin niteliksel özellikleri

- Finansal tabloları oluşturan unsurların tanımı, tahakkuku ve ölçülme esasları

- Sermaye ve sermayenin sürekliliği ve korunması kavramları

TFRS 2016 setindeki 15 adet finansal raporlama standardı aşağıdaki gibidir (TFRS 2016 Seti) ${ }^{1}$.

1. Türkiye Finansal Raporlama Standartlarının Ilk Uygulanması: İşletmelerdeki TFRS' lerin ilk kez uygulandığı finansal tabloları için uygulama esaslarını belirtmektedir.

2. Hisse Bazlı Ödemeler: Bir işletmenin hisse bazlı ödeme işlemlerini gerçekleştirmesindeki etkilerinin finansal tablolarında gösterilmesini zorunlu kılan standarttır. Öz kaynağa dayalı hisse bazlı ödemeler, nakit şekilde ödenen hisse bazlı ödemeler, ürün veya hizmet alımındaki durumu kapsamak üzere üç madde bu standardın genel çerçevesini oluşturmaktadır.

\footnotetext{
${ }^{1}$ http://kgk.gov.tr, Erişim Tarihi: 10.09.2016
} 
3. İşletme Birleşmeleri: İşletme birleşmelerindeki birleşme sürecini, tanımlanabilir varlıklarını, borçlarını, birleşme sonucundaki kazancını ve şerefiyenin ölçümünü, muhasebeleştirilip finansal tablolarda nasıl yer alması gerektiğini açıklayan standarttır.

4. Sigorta Sözleşmeleri: Bu TFRS' nin amacı, sigorta sözleşmesini düzenleyen herhangi bir sigortac1 işletmenin sigorta sözleşmelerinden kaynaklanan gelecekteki nakit akışlarının tutarını, zamanlamasını, sözleşmenin iyileştirilmesine yönelik finansal raporlamanın nasıl olması gerektiğini açıklamaktadır.

5. Satış Amaçlı Elde Tutulan Duran Varlıklar ve Durdurulan Faaliyetler: Satış amaçlı işletme bünyesinde bulundurulan varlıkların muhasebeleştirilme esaslarını ve finansal raporlamanın nasıl yapılması gerektiğini açıklayan standarttır.

6. Maden Kaynaklarının Araştırılması ve Değerlendirilmesi: $\mathrm{Bu}$ standart maden kaynaklarının araştırılması ve değerlendirilmesindeki varlıkları ve kaynakların araştırılıp değerlendirilmesi sonucunu içeren sürecin finansal tablolarda açıklanmasını belirlemektedir.

7. Finansal Araçlar - Açıklamalar: Bir işletmenin raporlama dönemine kadar finansal araçlar nedeniyle katlandığı riskleri ve bu finansal araçların nasıl yönetildiğine ilişkin finansal tablo kullanıcılarına açıklamaları kapsayan bir finansal raporlama standardıdır.

8. Faaliyet Bölümleri: Bir işletmenin gerçekleştirdiği faaliyetlerini ve faaliyetlerini gerçekleştirme sürecindeki ekonomik finansal etkilerinin değerlendirilmesini finansal tablolarda açıklanmasını içeren standarttır.

9. Finansal Araçlar: İ̧̧letmenin finansal varlıklarının tutarını, gelecekteki nakit akışlarının değerlendirilmesin finansal tablo kullanıcılarına faydalı finansal bilgiyi sunmak amacinı içermektedir. Finansal varlıkların muhasebeleştirilmesi, sınıflandırılması, ölçülmesi, finansal risklerinin belirlenmesi sürecini açıklayan standarttır.

10. Konsolide Finansal Tablolar: Bir işletmenin diğer bir veya birden fazla işletmeyi kontrol ettiğinde düzenlenmesi gereken konsolide finansal tabloların raporlanması ilkelerini belirlemektedir.

11. Müşterek Anlaşmalar: Müşterek antlaşmalarda payı olan işletmeler tarafından finansal tabloların nasıl hazırlanması gerektiğini açıklamaktadır.

12. Diğer İşletmelerdeki Paylara İlişsin Açıklamalar: Bağlı ortaklıklar, müşterek antlaşmalar, iştirakler, konsolide edilmeyen yapılandırılmış işletmeler tarafından bu TFRS uygulanmasını kapsamaktadır. İşletmenin, diğer işletmedeki paylarının niteliğinin finansal tablolarda açıklanmasını sağlamaktadır.

13. Gerçeğe Uygun Değer Ölçümü: İşletme bünyesinde bulunan varlıklar ve borçların gerçeğe uygun değerle nasıl ölçülmesi gerektiğini açılayan TFRS' dir. Gerçeğe uygun değer tanımı, değerleme yöntemlerini, muhasebeleştirilmesini açıklamaktadır.

14. Düzenlemeye Dayalı Erteleme Hesapları: Bir işletmenin tarife düzenlenmesine tabi faaliyetlerini ve bu faaliyetleri sırasında müşterilerine bu tarife sonucunda sunduğu mal ve hizmetler nedeniyle oluşan düzenlemeye dayalı erteleme hesap bakiyeleriyle ilgili finansal raporlamanın nasıl yapılması gerektiğini açıklar.

15. Müşteri Sözleşmelerinden Hasılat: Bu standart müşteri sözleşmelerinden kaynaklanan nakit akışlarıyla ilgili finansal raporlama hükümlerini açıklar.

\section{TÜRKIYE FINANSAL RAPORLAMA STANDARTLARI'YLA ILGILI YAPILMIŞ OLAN ÇALIŞMALAR}

Çalışma kapsamına Türkiye Finansal Raporlama Standartları ve muhasebe meslek mensuplarına uygulanmasının birlikte yer aldığ Raporlama Standartlarıyla (TFRS) ilgili muhasebe meslek mensuplarına yönelik yapılmış çalışmalar Tablo 1'de listelenmiştir. Ayrıca aynı konuyla ilgili yazılmış olan lisansüstü tezler araştırma kısıtları getirilerek liste şeklinde Tablo 2'de belirtilmiştir. Sempozyum ve kongrelerde 
sunulmuş olan bildirilerin çoğunluğunun web ortamında bulunmaması nedeniyle bildiriler kapsam dışı bırakılmıştır.

Yücel ve diğerleri tarafından 2015 yılında yayınlanmış “Türkiye'de Muhasebe ve Finansal Raporlama Standartları Konularında Yayınlanmış Akademik Çalışmalar (2007-2014 Arası Literatür Taramas1)" başlıklı makalede tek bir finansal raporlama standardının incelendiği çalışmalar 31 makale, 32 lisansüstü tez çalışması olmak üzere toplam 63 akademik çalışmanın yer aldığı görülmektedir. Küçük ve Orta Büyüklükte İşletmeler İçin Türkiye Finansal Raporlama Standardı (KOBİ TFRS) konusuna odaklanan 26 makale, 28 lisansüstü tez çalışması olmak üzere toplamda 54 bilimsel çalışma yer almaktadır. 2007-2014 yılları aralığında Türkiye Muhasebe Standartları ve Türkiye Finansal Raporlama Standartlarını içeren toplam 857 makale ve tezin yer aldığı görülmektedir. Bu çalışma sonucu ortaya çıkan rakamlar Türkiye' de günümüz itibariyle muhasebe standartlarıyla ilgili bilgi eksikliğinin minimum seviyede olması gerektiğini göstermektedir.

\section{Tablo 1.TFRS/KOBİ TFRS' nin Muhasebe Meslek Mensuplarıyla Birlikte Yer Aldığı} Makaleler

\begin{tabular}{|c|c|c|c|c|c|c|}
\hline No & Yayın Adı & Yazar(lar)ı & $\begin{array}{l}\text { Yayın } \\
\text { Yllı }\end{array}$ & $\begin{array}{l}\text { Yayınlandığı/ } \\
\text { Sunulduğu } \\
\text { Yer }\end{array}$ & Çalışmanın Amacı & Çalışmanın Bulguları \\
\hline 1 & $\begin{array}{lr}\text { Türkiye } & \text { Muhasebe } \\
\text { Standartları } & \text { ve } \\
\text { Muhasebe Meslek } \\
\text { Mensuplarının Bilgi } \\
\text { Düzeylerinin } \\
\text { İncelenmesi }\end{array}$ & $\begin{array}{l}\text { Erdoğan ve } \\
\text { Dinç }\end{array}$ & 2009 & $\begin{array}{l}\text { Muhasebe ve } \\
\text { Finansman } \\
\text { Dergisi }\end{array}$ & $\begin{array}{l}\text { Muhasebe standartları } \\
\text { (TMS/TFRS) hakkında } \\
\text { muhasebe alanında } \\
\text { faaliyet gösteren meslek } \\
\text { elemanlarının } \\
\text { standartları uygulama } \\
\text { düzeyleri ve görüşlerinin } \\
\text { neler olduğu } \\
\text { amaçlanmıştır. }\end{array}$ & $\begin{array}{lr}\text { Araştırma } & \text { sonucunda; } \\
\text { meslek } & \text { elemanlarının } \\
\text { 1/3'ünün } & \text { standartlardan } \\
\text { haberdar } & \text { olmadıkları, } \\
\text { bilgilerinin } & \text { yetersiz } \\
\text { olduklarının, } & \text { eğitim } \\
\text { düzeyi daha yüksek } \\
\text { olanların } & \text { nispeten } \\
\text { bilgilerinin daha yüksek } \\
\text { olduğu bulguları yapılan } \\
\text { analizler neticesinde } \\
\text { bulunmuştur. }\end{array}$ \\
\hline 2 & $\begin{array}{l}\text { Türkiye'de } \\
\text { Uluslararası } \\
\text { Muhasebe } \\
\text { Standartları'nın } \\
\text { Uygulanabilirliğini } \\
\text { Etkileyen Faktörlerin } \\
\text { Meslek } \\
\text { Mensuplarınca } \\
\text { Değerlendirilmesine } \\
\text { Yönelik Bir } \\
\text { Araştırma }\end{array}$ & $\begin{array}{c}\text { Çankaya ve } \\
\text { Hatipoğlu }\end{array}$ & 2011 & $\begin{array}{l}\text { Uluslararası } \\
\text { İktisadi ve } \\
\text { İdari } \\
\text { İncelemeler } \\
\text { Dergisi }\end{array}$ & $\begin{array}{l}\text { IFRS temel alınarak } \\
\text { hazırlanan TMS ve } \\
\text { TFRS' nin Türkiye'de } \\
\text { uygulanması } \\
\text { benimsenmesinin } \\
\text { muhasebe ve meslek } \\
\text { mensuplarının düşünce } \\
\text { ve beklentilerinin neler } \\
\text { olduğunun belirlenmesi } \\
\text { amaçlanmıştır. }\end{array}$ & $\begin{array}{lr}\text { Araştırma } & \text { sonucunda; } \\
\text { TMS ve } & \text { TFRS } \\
\text { uygulanmas1 } & \text { ve } \\
\text { benimsenmesine } & \text { ilişkin } \\
\text { faktörler } 4 \text { temel faktöre } \\
\text { indirgenmiştir. Elde edilen } \\
\text { bulgular: eğitim } & \text { sorunu, } \\
\text { KOBI'lere r } & \text { uygun } \\
\text { olmayış1, standartların } \\
\text { çeviri sorunu, gibi } \\
\text { olumsuz rustur. } \\
\text { bulunmustar }\end{array}$ \\
\hline 3 & $\begin{array}{lr}\text { Türkiye } & \text { Finansal } \\
\text { Raporlama } & \\
\text { Standartlarının } \\
\text { Meslek Mensupları } \\
\text { Arasındaki } & \text { Bilinirlik } \\
\text { Düzeyini } & \text { Ölçmeye } \\
\text { Yönelik r rir } \\
\text { Araştırma } & \text { (Ankara } \\
\text { ve Çankırı İlleri } \\
\text { Örneği) }\end{array}$ & Can ve Gör & 2011 & $\begin{array}{l}\text { World Of } \\
\text { IFRS }\end{array}$ & \begin{tabular}{lcr}
$1 \quad$ Ocak & 2013 tarihi \\
itibariyle & \multicolumn{2}{c}{ TFRS } \\
uygulama & zorunluluğu \\
getirilen, Ankara ve & Acankırı İllerinde 142 \\
meslek & mensubunun \\
bilgi & düzeyinin \\
ölçülmesi amaçlanmıştır.
\end{tabular} & $\begin{array}{lrr}\text { Araştırma } & \text { sonucunda; } \\
\text { meslek } & \text { mensuplarının } \\
\text { yeterli } & \text { bilgiye } & \text { sahip } \\
\text { olduğu ancak } & \text { sistematik } \\
\text { eğitime } & & \text { ihtiyaç } \\
\text { duydukları, } & \text { bağlı } \\
\text { bulundukları } & \text { meslek } \\
\text { odalarının } & \text { standartlarla } \\
\text { ilgili } & \text { çalışmalarını } \\
\text { yetersiz } & \text { olduğu tespit }\end{array}$ \\
\hline
\end{tabular}




\begin{tabular}{|c|c|c|c|c|c|c|}
\hline & & & & & & edilmiştir. \\
\hline 4 & $\begin{array}{l}\text { Muhasebe Meslek } \\
\text { Mensuplarının } \\
\text { TFRS' ye Yönelik } \\
\text { Bir Araştırma - } \\
\text { Trabzon Alt Bölgesi } \\
\text { Örneği }\end{array}$ & $\begin{array}{l}\text { Dinç ve } \\
\text { Atabay }\end{array}$ & 2011 & $\begin{array}{l}\text { World Of } \\
\text { IFRS }\end{array}$ & $\begin{array}{l}\text { Trabzon ili ve } \\
\text { etrafındaki } \\
\text { müşavirlerin } \\
\text { standartlarla ilgili olan } \\
\text { bilgi düzeylerinin } \\
\text { ölçülmesi ve uygulama } \\
\text { sirasindaki muhtemel } \\
\text { faktörleri belirlemek. }\end{array}$ & \begin{tabular}{lc} 
Araştırma & \multicolumn{2}{c}{ sonucunda; } \\
meslek mensuplarının \\
fazla iş yükü ve \\
kısıman \\
bilgi nedeniyle & yeterli \\
olmadizeyine & sahip \\
edilmiştir. & tespit \\
&
\end{tabular} \\
\hline 5 & $\begin{array}{l}\text { Muhasebe Meslek } \\
\text { Mensuplarının KOBİ } \\
\text { TFRS' ye Yönelik } \\
\text { Bilgi Düzeyleri ve } \\
\text { Uygulamaya } \\
\text { Yönelik Beklentileri: } \\
\text { Elazı̆g ve Malatya } \\
\text { İlleri Örneği başlıklı } \\
\text { makalesi }\end{array}$ & $\begin{array}{l}\text { Güneş ve } \\
\text { Diğerleri }\end{array}$ & 2011 & $\begin{array}{l}\text { World Of } \\
\text { IFRS }\end{array}$ & 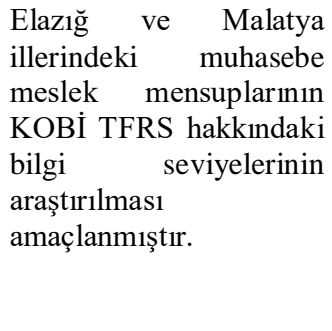 & $\begin{array}{l}\text { Araştırma sonucunda; } \\
\text { katılımcıların KOBİ TFRS } \\
\text { hakkında bilgi } \\
\text { düzeylerinin eksik olduğu, } \\
\text { KOBI TFRS ile ilgili } \\
\text { etkinliklere katılımın az } \\
\text { olduğu bulgularına } \\
\text { ulaşılmıştır. }\end{array}$ \\
\hline 6 & $\begin{array}{l}\text { Muhasebe Meslek } \\
\text { Mensupları } \\
\text { Perspektifinden } \\
\text { Türkiye Muhasebe } \\
\text { Standartları }\end{array}$ & $\begin{array}{l}\text { Elitaş ve } \\
\text { Diğerleri }\end{array}$ & 2011 & $\begin{array}{l}\text { World Of } \\
\text { IFRS }\end{array}$ & $\begin{array}{l}\text { Afyon, Denizli ve Uşak } \\
\text { illerinde görev yapan } \\
\text { muhasebe } \\
\text { mensuplarına meslek } \\
\text { uygulanarak, muhasebe } \\
\text { standartlarına yönelik } \\
\text { bilgi düzeyi ölçülmesi } \\
\text { amaçlanmıştır. }\end{array}$ & $\begin{array}{l}\text { Araştırma sonucunda; } \\
\% 80 \text { meslek mensubunun } \\
\text { TMS hakkında yeterli } \\
\text { bilgiye sahip olduğu, } \\
\text { ancak verilen eğitimlerin } \\
\text { yeterli olmadığını, } 16 \text { yıl } \\
\text { ve üzerindeki meslek } \\
\text { mensuplarının TMS } \\
\text { nedeniyle mesleği } \\
\text { burakmayı düşündükleri } \\
\text { bulunmuştur. }\end{array}$ \\
\hline 7 & $\begin{array}{l}\text { Serbest Muhasebeci } \\
\text { ve Mali Müşavirlerin } \\
\text { Yeni Türk Ticaret } \\
\text { Kanunu ve Türkiye } \\
\text { Finansal Raporlama } \\
\text { Standartları } \\
\text { Farkındalığı: } \\
\text { Marmara Bölgesi } \\
\text { Örneği }\end{array}$ & $\begin{array}{l}\text { Dabbağoğlu } \\
\text { ve Can }\end{array}$ & 2011 & $\begin{array}{l}\text { Anadolu Bil } \\
\text { Meslek } \\
\text { Yüksekokulu } \\
\text { Dergisi }\end{array}$ & $\begin{array}{l}\text { Marmara bölgesindeki } \\
\text { SMMM' lerin TFRS } \\
\text { konusundaki } \\
\text { gelişmelerle ne kadar } \\
\text { ilgili olduklarının } \\
\text { ölçülmesi amaçlanmıştır. }\end{array}$ & $\begin{array}{l}\text { Çanakkale, } \\
\text { Bursa, Edirne, İstanbul, } \\
\text { Kırklareli ve Tekirdağ } \\
\text { olmak üzere } 7 \text { ilden } 56 \\
\text { meslek mensubunun } \\
\text { katıllımiyla ilgili web } \\
\text { siteleri üzerinden anket } \\
\text { yöntemi uygulanmiştır. } \\
\text { SMMM' lerin TFRS ile } \\
\text { ilgili gelişmeleri takip } \\
\text { ettikleri sonucuna } \\
\text { ulaşılmıştır. }\end{array}$ \\
\hline 8 & $\begin{array}{l}\text { Muhasebe Meslek } \\
\text { Mensuplarının } \\
\text { Türkiye Muhasebe } \\
\text { ve Finansal } \\
\text { Raporlama } \\
\text { Standartlarına Bakış } \\
\text { Açılarının } \\
\text { Ölçülmesine İlişkin } \\
\text { Ampirik Bir Çalışma }\end{array}$ & $\begin{array}{l}\text { Erol ve } \\
\text { Diğerleri }\end{array}$ & 2011 & MÖDAV & $\begin{array}{l}\text { Çalışma ilgili yazarlar } \\
\text { Çanakkale merkezi ve } \\
\text { Biga ilçesindeki meslek } \\
\text { mensuplarının } \\
\text { TMS/TFRS' lere yönelik } \\
\text { düşüncelerinin } \\
\text { değerlendirilmesini } \\
\text { amaçlamışlardır. }\end{array}$ & 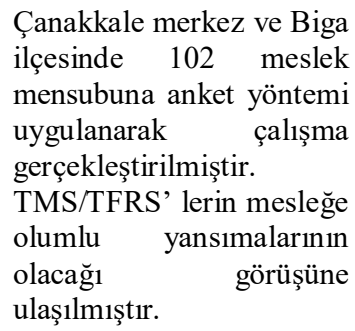 \\
\hline 9 & $\begin{array}{l}\text { KOBI'lerde UFRS } \\
\text { Uygulamalarını } \\
\text { Denetim Üzerine } \\
\text { Olas1 Etkilerini }\end{array}$ & $\begin{array}{l}\text { Kurtçu ve } \\
\text { Akdoğan }\end{array}$ & 2011 & $\begin{array}{c}\text { Hitit } \\
\text { Üniversitesi } \\
\text { Sosyal } \\
\text { Bilimler }\end{array}$ & 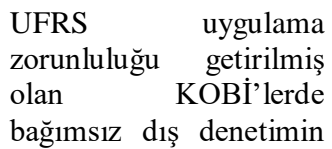 & $\begin{array}{lrr}\text { Amasya } & \text { ve } & \text { Çorum } \\
\text { illerindeki } & & \text { meslek } \\
\text { mensuplarına } & \text { uygulanmış } \\
105 & & \text { anket }\end{array}$ \\
\hline
\end{tabular}




\begin{tabular}{|c|c|c|c|c|c|c|}
\hline & $\begin{array}{lr}\text { Görmek } & \text { Amaciyla } \\
\text { Serbest Muhasebeci } \\
\text { ve Mali Müşavir İle } \\
\text { Yeminli r Mali } \\
\text { Müşavirler Üzerine } \\
\text { Bir Araştırma }\end{array}$ & & & $\begin{array}{l}\text { Enstitüsü } \\
\text { Dergisi }\end{array}$ & $\begin{array}{l}\text { olası etkilerini } \\
\text { ölçebilmek için Amasya } \\
\text { ve Çorum illerinde } \\
\text { faaliyet gösteren meslek } \\
\text { mensuplarını kapsayan } \\
\text { araştırma } \\
\text { gerçekleştirilmiştir. }\end{array}$ & $\begin{array}{l}\text { değerlendirilmesi } \\
\text { sonucunda UFRS ile ilgili } \\
\text { bilgilendirmenin yetersiz } \\
\text { olduğuna ulaşılmıştır. } \\
\text { Bilgilendirme } \\
\text { çalışmalarına önem } \\
\text { verilmesinin bağımsız } \\
\text { denetim kalitesine etkisi } \\
\text { olacağı görşü yer } \\
\text { almaktadır. }\end{array}$ \\
\hline 10 & $\begin{array}{l}\text { Meslek } \\
\text { Mensuplarının } \\
\text { UFRS' ye Bakış } \\
\text { Açıları } \\
\text { Farkındalık } \\
\text { Düzeyleri Üzerine } \\
\text { Bir Araştırma }\end{array}$ & $\begin{array}{c}\text { Kurcan ve } \\
\text { Diğerleri }\end{array}$ & 2011 & $\begin{array}{l}\text { Muhasebe ve } \\
\text { Vergi } \\
\text { Uygulamaları } \\
\text { Dergisi }\end{array}$ & $\begin{array}{l}\text { Antalya ve Alanya' da } \\
\text { aktif olarak çalışan } \\
\text { meslek mensuplarının } \\
\text { muhasebe standartları } \\
\text { hakkındaki görüsslerinin } \\
\text { değerlendirilmesi } \\
\text { amaçlanarak araştırma } \\
\text { yapılmıştır. }\end{array}$ & 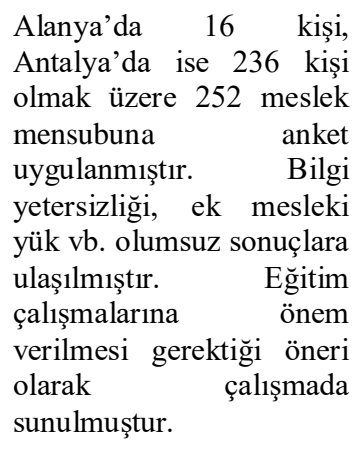 \\
\hline 11 & $\begin{array}{l}\text { Uluslararası Finansal } \\
\text { Raporlama } \\
\text { Standartlarına Uyum } \\
\text { Süreci ve Muhasebe } \\
\text { Meslek } \\
\text { Mensuplarının Bilgi } \\
\text { Düzeylerinin } \\
\text { İncelenmesi } \\
\text { (Marmaris İlçesi } \\
\text { Örneği) }\end{array}$ & $\begin{array}{l}\text { Köroğlu ve } \\
\text { Doğan }\end{array}$ & 2012 & $\begin{array}{l}\text { World Of } \\
\text { IFRS }\end{array}$ & $\begin{array}{lr}\text { Türkiye } & \text { Finansal } \\
\text { Raporlama Standartlar1 } \\
\text { (TFRS) 'yla ilgili } \\
\text { muhasebe mesleğini icra } \\
\text { edenlerin bilgi seviyeleri } \\
\text { anket uygulanarak } \\
\text { ölçülmesi amaçlanmıştır. }\end{array}$ & $\begin{array}{lr}\text { Araştırma sonucu; } & \text { meslek } \\
\text { mensuplarının } & \text { yeterli } \\
\text { derecede bilgi } & \text { sahibi } \\
\text { olmadıkları } & \text { tespit } \\
\text { edilmiştir. } & \end{array}$ \\
\hline 12 & $\begin{array}{l}\text { KOBI'ler için } \\
\text { TFRS' nin Getirdiği } \\
\text { Yenilikler ver ve } \\
\text { Uygulanabilirliği } \\
\text { Üzerine Ankara } \\
\text { İlinde Bir Araştırma }\end{array}$ & $\begin{array}{l}\text { Hachhasanoğlu } \\
\text { ve Diğerleri }\end{array}$ & 2012 & $\begin{array}{l}\text { World Of } \\
\text { IFRS }\end{array}$ & $\begin{array}{lr}2013 & \text { yılında } \\
\text { uygulamaya girecek olan } \\
\text { KOBİ TFRS için Ankara } \\
\text { ilindeki meslek } \\
\text { mensuplarının } \\
\text { uygulamaya hazır olup } \\
\text { olmadıklarının ve bilgi } \\
\text { düzeylerinin ölçülmesi } \\
\text { için yazarlar tarafından } \\
\text { araştırma yapılmıştır. }\end{array}$ & $\begin{array}{l}\text { Ankara ilinde e-posta yolu } \\
\text { üzerinden } 313 \text { SMMM' } \\
\text { nin katılımıyla anket } \\
\text { uygulaması } \\
\text { gerçekleştirilmiştir. } \\
\text { Çalışmada SMMM' lerin } \\
\text { iş yükünün artacağ1 } \\
\text { görüşünün yüksek olduğu } \\
\text { ve standartların } \\
\text { işletmelere olumlu } \\
\text { gelişmeler sağlayacağ1 } \\
\text { sonucuna ulaşılmıştır. }\end{array}$ \\
\hline 13 & $\begin{array}{lr}\text { Muhasebe } & \text { Meslek } \\
\text { Mensuplarının } & \text { TTK, } \\
\text { TMS/TFRS } & \text { ve } \\
\text { KOBI } & \text { TFRS IIle } \\
\text { İlgili rärlene } & \text { Genel } \\
\text { Görüşleri: } & \text { Erzincan } \\
\text { Örneği } & \end{array}$ & Yildırım & 2012 & $\begin{array}{l}\text { Erzincan } \\
\text { Üniversitesi } \\
\text { Sosyal } \\
\text { Bilimler } \\
\text { Enstitüsü } \\
\text { Dergisi }\end{array}$ & $\begin{array}{lr}\text { Erzincan'da } & 2012 \\
\text { yılında 42 } & \text { muhasebe } \\
\text { meslek mensubuna TTK, } \\
\text { TMS/TFRS ve KOBİ } \\
\text { TFRS konularındaki } \\
\text { gelişmeler hakkındaki } \\
\text { görüşlerini } \\
\text { amacıyla almak } \\
\text { tarafindan Yildırım } \\
\text { gerçekleştirilmiştir. }\end{array}$ & $\begin{array}{lrr}\text { Çalışma } & \text { sonucunda } \% 86 \\
\text { meslek mensubu ilgili } \\
\text { eğitimlere } & \text { katılmalarına } \\
\text { rağmen } & \text { TMS/TFRS } \\
\text { konusunda } & \text { tekrar eğitime } \\
\text { ihtiyaç } & \text { duydukların1 } \\
\text { belirtmiştir. } & \% 88 \\
\text { TMS/TFRS } & \text { ile ilgili } \\
\text { kendilerine yeterli bilgi } \\
\text { verilmediği ve (33 kişi } \\
\text { lisans mezunu) } \% 72 \text { lisans } \\
\text { eğitimlerinde y yetersiz } \\
\text { olduğunu belirtmişlerdir. }\end{array}$ \\
\hline
\end{tabular}




\begin{tabular}{|c|c|c|c|c|c|c|}
\hline 14 & $\begin{array}{l}\text { Yeni Türk Ticaret } \\
\text { Kanunu'nun } \\
\text { Muhasebe Meslek } \\
\text { Mensupları } \\
\text { Açısından } \\
\text { Değerlendirilmesine } \\
\text { Yönelik Ampirik Bir } \\
\text { Çalışma }\end{array}$ & Bozdemir & 2012 & $\begin{array}{l}\text { Muhasebe ve } \\
\text { Finansman } \\
\text { Dergisi }\end{array}$ & $\begin{array}{lr}\text { Erzurum ilindeki Serbest } \\
\text { Muhasebeci } & \text { Mali } \\
\text { Müşavirler Odasına üye } \\
\text { meslek mensuplarına } \\
6102 \text { sayılı Türk Ticaret } \\
\text { Kanunu ile ilgili } \\
\text { görüşlerinin } & \text { anket } \\
\text { uygulaması } & \text { ile } \\
\text { değerlendirmesi } & \\
\text { yapılmıştır. } & \end{array}$ & $\begin{array}{l}\text { Araştırma sonucunda; } \\
\text { finansal tabloların daha } \\
\text { şeffaf olacağını, yeni } \\
\text { uygulamaların meslek } \\
\text { mensuplarına daha fazla } \\
\text { sorumluluk getireceği, } \\
\text { Vergi Usul Kanunu ile } \\
\text { Türk Ticaret Kanunu } \\
\text { arasında çelişkiler } \\
\text { olacağını, } \\
\text { muhasebesinden vergi } \\
\text { muhasebeciliğine } \\
\text { dönüşeceği bulgularına } \\
\text { ulaşılmıştır. }\end{array}$ \\
\hline 15 & $\begin{array}{l}\text { KOBILER İçin } \\
\text { Finansal Raporlama } \\
\text { Standardı ve Mali } \\
\text { Müşavirlerin } \\
\text { Uygulama Öncesi } \\
\text { İlgi Düzeylerine } \\
\text { Yönelik Ampirik Bir } \\
\text { Araştırma }\end{array}$ & Özdemir & 2012 & $\begin{array}{l}\text { Muhasebe ve } \\
\text { Denetime } \\
\text { Bakış Dergisi }\end{array}$ & $\begin{array}{lr}\text { Araştırma Ankara } \\
\text { SMMM odasına bağli } \\
\text { internet üzerinden } & \text { anket } \\
\text { uygulamasıyla } & \\
\text { 883SMMM'lerin } & \text { ilgi } \\
\text { düzeylerinin } & \\
\text { değerlendirilmesi } & \\
\text { amaciyla } & \\
\text { gerçekleştirilmiştir. }\end{array}$ & $\begin{array}{lr}\text { Araştırma } & \text { sonucunda; } \\
\text { meslek mensuplarının } \\
\text { KOBİ TFRS ye karş1 } \\
\text { yüksek derecede ilgi } \\
\text { duyduklarına, meslekte } \\
\text { yeni olan } & \text { meslek } \\
\text { uygulayıcılarının } & \text { ise } \\
\text { deneyimli } & \text { meslek } \\
\text { mensuplarına göre ilgi } \\
\text { düzeyi yüksek grup, } \\
\text { mükellef sayıları az olan } \\
\text { SMMM' lerin yüksek ilgi } \\
\text { düzeyi olduğu sonuçlarına } \\
\text { ulaşılmıştır. }\end{array}$ \\
\hline 16 & $\begin{array}{l}\text { KOBI Muhasebe } \\
\text { Standartlarının } \\
\text { Gelişimi ve } \\
\text { Ü̈rkiye } \\
\text { Urzerine } \\
\text { Araştırma }\end{array}$ & $\begin{array}{c}\text { Arsoy ve } \\
\text { Bora }\end{array}$ & 2012 & $\begin{array}{l}\text { Muhasebe ve } \\
\text { Finansman } \\
\text { Dergisi }\end{array}$ & $\begin{array}{lr}\text { Araştırma } & \text { Bursa ilinde } \\
\text { faaliyet } & \text { gösteren } \\
\text { SMMM odasına kayıtlı } \\
\text { görüşleri doğrultusunda } \\
\text { KOBİ } & \text { muhasebe } \\
\text { standartlarına } & \text { yönelik } \\
\text { SWOT } & \text { analizi } \\
\text { yapılması. } & \end{array}$ & $\begin{array}{lr}\text { Araştırma } & \text { sonucu; } \\
\text { muhasebe } & \text { meslek } \\
\text { mensupları görüslleri } \\
\text { doğrultusunda } & \text { alınan } \\
\text { cevaplarla birlikte } & \text { KOBİ } \\
\text { standartlarını uygulamann } \\
\text { en güçlü yönü doğru ve } \\
\text { şeffaf bir finansal } \\
\text { raporlama, zayıf yönü ise } \\
\text { uluslararası standartların } \\
\text { çevrilmesinden } \\
\text { kaynaklanan anlaşllma } \\
\text { zorluğudur. }\end{array}$ \\
\hline 17 & $\begin{array}{l}\text { Yeni Türk Ticaret } \\
\text { Kanunu } \\
\text { TFRS/TMS İle } \\
\text { Konusunda Getirilen } \\
\text { Yenilikler ve Ordu } \\
\text { İli Muhasebe Meslek } \\
\text { Mensuplarının Bakış } \\
\text { Açılarını } \\
\text { Değerlendirmeye } \\
\text { Yönelik Bir } \\
\text { Uygulama }\end{array}$ & $\begin{array}{l}\text { Yel ve } \\
\text { Çiftçi }\end{array}$ & 2013 & $\begin{array}{l}\text { Muhasebe ve } \\
\text { Vergi } \\
\text { Uygulamaları } \\
\text { Dergisi }\end{array}$ & 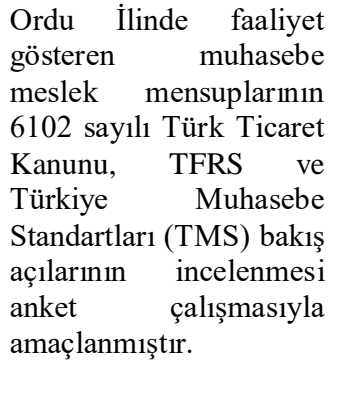 & $\begin{array}{lr}\text { Araştırma } & \text { sonucunda; } \\
\text { cinsiyetlere } & \text { göre } \\
\text { algılamalarda } & \text { farklılık } \\
\text { olmadı̆̆ı, eğitim, unvanla } \\
\text { ilgili anlamlı farklılıklar } \\
\text { olduğu } & \text { sonucuna } \\
\text { ulaşılmıştır. } & \end{array}$ \\
\hline 18 & $\begin{array}{l}\text { Türkiye Finansal } \\
\text { Raporlama } \\
\text { Standartları'nın } \\
\text { Bilinirlik Düzeyi } \\
\text { Üzerine }\end{array}$ & $\begin{array}{l}\text { Hatunoğlu } \\
\text { ve Diğerleri }\end{array}$ & 2013 & $\begin{array}{l}\text { Niğde } \\
\text { Üniversitesi } \\
\text { İIBBF Dergisi }\end{array}$ & $\begin{array}{l}\text { Kahramanmaraş'ta } \\
\text { faaliyet gösteren } 46 \\
\text { işletmede çalışma } \\
\text { gerçekleştirilmiştir. Bu } \\
\text { işletmelerdeki }\end{array}$ & $\begin{array}{lr}\text { KOBİ niteliğindeki } & 46 \\
\text { işletmenin } & \text { sorumlu } \\
\text { muhasebe yöneticilerinden } \\
\text { alınan r bilgiler } \\
\text { doğrultusunda, } & \text { standartlar }\end{array}$ \\
\hline
\end{tabular}




\begin{tabular}{|c|c|c|c|c|c|c|}
\hline & $\begin{array}{l}\text { Kahramanmaraş'ta } \\
\text { Bir Alan Çalışması }\end{array}$ & & & & $\begin{array}{l}\text { muhasebeden sorumlu } \\
\text { olan yöneticilerine } \\
\text { TFRS' nin etkilerine ait } \\
\text { görüşlerinin } \\
\text { değerlendirilmesi } \\
\text { amaçlanmiştır. }\end{array}$ & $\begin{array}{l}\text { hakkında tam olarak bilgi } \\
\text { sahibi olmadıklarını ancak } \\
\text { işletmeye uygulama } \\
\text { sonrasında olumlu etkileri } \\
\text { olacağını belirten } \\
\text { sonuçlara ulaşılmıştır. }\end{array}$ \\
\hline 19 & $\begin{array}{lr}\text { Muhasebe } & \\
\text { Akademisyenlerinin } \\
\text { Muhasebe } \\
\text { Standartlarına } & \\
\text { Açılları } & \text { ve } \\
\text { Farkındalıkları } & \\
\text { Üzerine } & \text { Bir } \\
\text { Araştırma } & \end{array}$ & $\begin{array}{l}\text { Aktürk ve } \\
\text { Akcanlı }\end{array}$ & 2013 & $\begin{array}{l}\text { Muhasebe } \\
\text { Bilim } \\
\text { Dünyas1 } \\
\text { Dergisi }\end{array}$ & $\begin{array}{lr}\text { Kamu ve vakıf } \\
\text { üniversitelerini kapsayan } \\
63 \text { farklı üniversitede, } \\
227 \text { muhasebe } & \text { alanında } \\
\text { görev } & \text { yapan } \\
\text { akademisyene } & \text { anket } \\
\text { tekniğiyle } & \text { muhasebe } \\
\text { standartlarına } & \text { bakış } \\
\text { açıları } & \text { ve } \\
\text { farkındalıklarını } & \\
\text { araştırmak. } & \end{array}$ & $\begin{array}{l}\text { Araştırma sonucunda; } \\
\text { akademisyenlerin kendi } \\
\text { bilgi düzeylerini iyiye } \\
\text { yakın olarak bulunmasına } \\
\text { karşın diğer } \\
\text { akademisyenler hakkında } \\
\text { bilgi düzeyi zayı olarak } \\
\text { belirtmişlerdir. } \\
\text { Akademisyenler } \\
\text { standartların } \\
\text { uygulanmasında bilgi } \\
\text { eksikliği sorunu olacağını, } \\
\text { uluslararası entegrasyonun } \\
\text { sağlanması ve kurumsal } \\
\text { yönetimin yaygınlaşmas, } \\
\text { bağımsız denetimi } \\
\text { kolaylaştıracağı } \\
\text { sonuçlarına ulaşılmıştır. }\end{array}$ \\
\hline 20 & $\begin{array}{l}\text { Türkiye Finansal } \\
\text { Raporlama } \\
\text { Standartları } \\
\text { Çerçevesinde KOBİ } \\
\text { Muhasebe } \\
\text { Standartlarının } \\
\text { Muhasebe Meslek } \\
\text { Mensupları } \\
\text { Tarafından Alg1 } \\
\text { Düzeylerinin } \\
\text { Tespitine Yönelik } \\
\text { Uygulama (Eskişehir } \\
\text { İli Örneği) }\end{array}$ & $\begin{array}{l}\text { Fidan ve } \\
\text { Cinit }\end{array}$ & 2013 & $\begin{array}{l}\text { Muhasebe ve } \\
\text { Finansman } \\
\text { Dergisi }\end{array}$ & $\begin{array}{l}\text { Eskişehir İline kayıtlı } \\
\text { muhasebe meslek } \\
\text { mensuplarının TFRS ile } \\
\text { ilgili bilgi düzeylerinin } \\
\text { ölçülmesi ve uygulama } \\
\text { sirasindaki muhtemel } \\
\text { faktörleri belirlemek. }\end{array}$ & $\begin{array}{l}\text { Araştırma sonucu; TFRS, } \\
\text { KOBİ TFRS hakkında } \\
\text { araştırma örneklemini } \\
\text { oluşturan katılımcıların } \\
\text { yarısından fazlasının az } \\
\text { bilgili olduğu, \%79'unun } \\
\text { mesleği zorlaştıracağını, } \\
\% 19 \text { 'u KOBİ TFRS } \\
\text { uygulama norluğu } \\
\text { nedeniyle gesleği } \\
\text { bırakmayı düşündüğü, iş } \\
\text { yüklerinin artıracağ } \\
\text { ifadesi belirtilmiştir. }\end{array}$ \\
\hline 21 & $\begin{array}{l}1 \quad \text { Ocak } \quad 2013 \\
\text { Öncesinde Türkiye } \\
\text { Finansal Raporlama } \\
\text { Standartları } \\
\text { Çerçevesinde KOBİ } \\
\text { Muhasebe } \\
\text { Standartlarının } \\
\text { Muhasebe Meslek } \\
\text { Mensupları } \\
\text { Tarafindan Algısı } \\
\text { (Bursa İli Örneği) }\end{array}$ & $\begin{array}{l}\text { Fidan ve } \\
\text { Cinit }\end{array}$ & 2013 & $\begin{array}{l}\text { Muhasebe ve } \\
\text { Denetime } \\
\text { Bakış }\end{array}$ & $\begin{array}{l}\text { Bursa İli muhasebe } \\
\text { meslek uygulayıcılarının } \\
\text { TFRS ile ilgili bilgi } \\
\text { düzeylerinin ölçülmesi } \\
\text { ve uygulama sırasındaki } \\
\text { muhtemel faktörleri } \\
\text { belirlemek. }\end{array}$ & 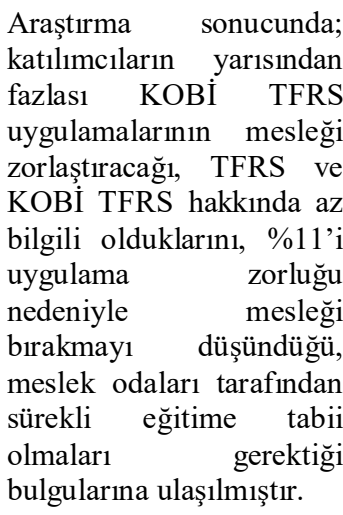 \\
\hline 22 & $\begin{array}{l}\text { Finansal Raporlama } \\
\text { Standartlarını } \\
\text { Öğrenme Sürecinde } \\
\text { Serbest Muhasebeci } \\
\text { Mali Müşavirlerin } \\
\text { Durumları: } \\
\text { Samsun'da Ampirik }\end{array}$ & Özdemir & 2013 & $\begin{array}{l}\text { Muhasebe ve } \\
\text { Denetime } \\
\text { Bakış }\end{array}$ & $\begin{array}{lr}\text { Çalışmada } & \text { muhasebe } \\
\text { alanındaki } & \text { meslek } \\
\text { sahiplerinin } & \text { standartları } \\
\text { öğrenmeye yönelik ilgi } \\
\text { düzeylerinin } & \text { farklı } \\
\text { değişkenlerle } & \text { (cinsiyet, } \\
\text { yaş, eğitim } & \text { vb.) }\end{array}$ & $\begin{array}{l}\text { Samsun ilinde } 86 \text { meslek } \\
\text { mensubuna } 35 \text { adet soru } \\
\text { içeren anket yöntemi } \\
\text { uygulanmıştır. Çalışmada } \\
\text { cinsiyet, yaş gruplar, } \\
\text { öğrenim düzeyleri ve } \\
\text { çalışma şekilleri }\end{array}$ \\
\hline
\end{tabular}




\begin{tabular}{|c|c|c|c|c|c|c|}
\hline & Bir Araştırma & & & & $\begin{array}{l}\text { ilişkisinin incelenmesi } \\
\text { amaçlanmıştır. }\end{array}$ & $\begin{array}{l}\text { bakımından öğrenme } \\
\text { isteğiyle ilgili anlamlı bir } \\
\text { farklılık bulunmamıştır. }\end{array}$ \\
\hline 23 & $\begin{array}{l}\text { Muhasebe Meslek } \\
\text { Mensuplarının } \\
\text { Eğitim Düzeyleri İle } \\
\text { Muhasebe } \\
\text { Standartlarına } \\
\text { Yönelik Algiları } \\
\text { Arasındaki } \quad \text { İlişki } \\
\text { Üzerine r Bir } \\
\text { Araştırma: Marmara } \\
\text { Bölgesi Örneği }\end{array}$ & $\begin{array}{l}\text { Fidan ve } \\
\text { Cinit }\end{array}$ & 2014 & $\begin{array}{l}\text { KMÜ Sosyal } \\
\text { ve Ekonomik } \\
\text { Araştırmalar } \\
\text { Dergisi }\end{array}$ & $\begin{array}{l}\text { Fidan ve Cinit tarafından } \\
2014 \text { y1lında Marmara } \\
\text { bölgesini kapsayacak } \\
\text { şekilde yapmiş oldukları } \\
\text { bu çalışmada TFRS ve } \\
\text { KOBİ TFRS' lerin alg1 } \\
\text { düzeyi ölçümü ve eğitim } \\
\text { durumuyla ilişkisinin } \\
\text { incelenmesi } \\
\text { amaçlanmıştır. }\end{array}$ & $\begin{array}{l}\text { Marmara bölgesini } \\
\text { kapsayan 11 ilde Yeminli } \\
\text { Mali Müşavirler kapsam } \\
\text { dişı olmak üzere toplamda } \\
950 \text { meslek mensubu } \\
\text { araştırmaya katılmıştır. } \\
\text { Araştırma sonucunda, } \\
\text { TFRS hakkındaki bilgi } \\
\text { seviyelerinin "lisans ve } \\
\text { lisansüstü eğitim mezunu" } \\
\text { ile "lise ve ön lisans } \\
\text { eğitim mezunu" kişiler } \\
\text { arasında anlaml } \\
\text { farkll1ıklar olduğu tespit } \\
\text { edilmiştir. }\end{array}$ \\
\hline 24 & 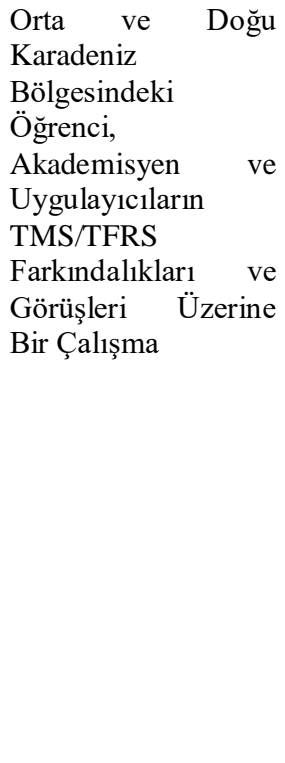 & $\begin{array}{l}\text { Y1lmaz ve } \\
\text { Diğerleri }\end{array}$ & 2014 & $\begin{array}{l}\text { Muhasebe } \\
\text { Bilim } \\
\text { Dünyası } \\
\text { Dergisi }\end{array}$ & $\begin{array}{l}\text { TMS/TFRS farkındalık } \\
\text { düzeyinin araştırılması } \\
\text { amaciyla işletme } \\
\text { bölümünde son sinıftaki } \\
\text { eğitim alan öğrencileri, } \\
\text { akademisyenleri ve } \\
\text { muhasebe meslek } \\
\text { mensupları olmak üzere } \\
\text { üç ayrı grubu kapsayan } \\
\text { çalışma } \\
\text { gerçekleştirilmiş̧ir. }\end{array}$ & $\begin{array}{l}\text { Araştırma kapsamında alt1 } \\
\text { üniversiteden } 489 \text { öğrenci, } \\
\text { muhasebe eğitiminde } \\
\text { görevli } 14 \text { akademisyen, } \\
\text { 46 SMMM yer almaktadır. } \\
\text { Mezun olduktan sonra } \\
\text { akademisyenlik ve mali } \\
\text { müşavirlik mesleğini } \\
\text { tercih edecek ögrencilerin } \\
\text { diğer öğrencilere göre } \\
\text { TMS/TFRS hakkında } \\
\text { farkındalı düzeylerinin } \\
\text { yüksek olduğ, } \\
\text { akademisyenlerin } \\
\text { öğrencilere göre kendi } \\
\text { bilgi becerileri } \\
\text { farkıle } \\
\text { yüksek olduğu, SMMM' } \\
\text { lerin ise standartlarla ilgili } \\
\text { eğitime ihtiyaç duyduklar1 } \\
\text { sonuçlarına ulaşılmıştır. }\end{array}$ \\
\hline 25 & $\begin{array}{l}\text { Niğde İlindeki } \\
\text { Muhasebe Meslek } \\
\text { Mensuplarının } \\
\text { Finansal Raporlama } \\
\text { Standartlarına Bakış } \\
\text { Açılarının Ampirik } \\
\text { Olarak } \\
\text { Değerlendirilmesi }\end{array}$ & $\begin{array}{l}\text { Bengü ve } \\
\text { Diğerleri }\end{array}$ & 2014 & $\begin{array}{l}\text { Niğde } \\
\text { Üniversitesi } \\
\text { İİBF Dergisi }\end{array}$ & $\begin{array}{l}\text { Niğde ilindeki muhasebe } \\
\text { meslek mensuplarının } \\
\text { öğrenim düzeyi, yaşı vb. } \\
\text { demografik özellikleri } \\
\text { dikkaterate alınarak } \\
\text { standartlara dair bakış } \\
\text { açılarının } \\
\text { değerlendirilmesi } \\
\text { amaçlanmıştır. }\end{array}$ & \begin{tabular}{lr} 
Araştırma & \multicolumn{2}{r}{ sonucunda; } \\
deneyimli olan meslek \\
mensuplarının s1k sık \\
güncellenen standartların \\
sorun olacağını, etik \\
değerlerle \\
doğrultuda paralel \\
güvenin muhasebede \\
sonuçlarına ulaşılmıştır.
\end{tabular} \\
\hline 26 & $\begin{array}{l}\text { Muhasebe Meslek } \\
\text { Mensuplarının } \\
\text { Muhasebe } \\
\text { Standartlarına } \\
\text { Uyumu Sürecinde } \\
\text { Eğitim Faktörü } \\
\text { Üzerine Antalya } \\
\text { İlinde Bir Araştırma }\end{array}$ & Aktürk & 2014 & $\begin{array}{l}\text { Mali Çözüm } \\
\text { Dergisi }\end{array}$ & $\begin{array}{lr}\text { Muhasebe } & \text { meslek } \\
\text { mensuplarının muhasebe } & \text { standartlarına } \\
\text { sürecindeki uyum } & \text { eğitim } \\
\text { faktörü üzerine } & \text { Antalya } \\
\text { ilinde bir araştırma } \\
\text { gerçekleştirilmiştir. }\end{array}$ & $\begin{array}{lr}\text { Örneklemi } & \text { oluşturan } 346 \\
\text { meslek } & \text { mensubuna } \\
\text { yönelik } & \text { araştırma } \\
\text { sonucunda, } & \text { muhasebe } \\
\text { standartları } & \text { hakkında } \\
\text { yetersiz bilgiye sahip } \\
\text { oldukları } \\
\text { ulaşılmıştır. Bu yetersiz } \\
\text { bilgi sonucu meslek } \\
\text { mensuplarında stres ve }\end{array}$ \\
\hline
\end{tabular}




\begin{tabular}{|c|c|c|c|c|c|c|}
\hline & & & & & & $\begin{array}{l}\text { kayg1 oluştuğu } \\
\text { gözlemlenmiştir. }\end{array}$ \\
\hline 27 & $\begin{array}{l}\text { Muhasebe } \\
\text { Standartlarının } \\
\text { Uygulanma } \\
\text { Sürecinde Muhasebe } \\
\text { Meslek } \\
\text { Mensuplarının } \\
\text { Standartlara Bakış } \\
\text { Açllarının ve } \\
\text { Mesleki } \\
\text { Yetkinliklerinin } \\
\text { İncelenmesi Üzerine } \\
\text { Balıkesir İlinde Bir } \\
\text { Araştırma }\end{array}$ & $\begin{array}{l}\text { Abdioğlu } \\
\text { ve Diğerleri }\end{array}$ & 2014 & $\begin{array}{c}\text { Eskişehir } \\
\text { Osmangazi } \\
\text { Üniversitesi } \\
\text { İIBF Dergisi }\end{array}$ & $\begin{array}{l}\text { Abdioğlu ve diğerleri } \\
\text { tarafından yapılmış } \\
\text { çalışmada, muhasebe } \\
\text { meslek mensuplarının } \\
\text { muhasebe standartları } \\
\text { hakkındaki fikirleri, bilgi } \\
\text { ihtiyacı, mesleki beceri, } \\
\text { mesleki etik, mesleki } \\
\text { tutum ve davranışları } \\
\text { açısından } \\
\text { incelemişlerdir. }\end{array}$ & $\begin{array}{l}53 \text { adet } \\
\text { olduğu } 191 \text { muhasebe } \\
\text { meslek mensubuna anket } \\
\text { yöntemi uygulanmıştır. } \\
\text { Araştırma sonucunda } \\
\text { muhasebe standartlarına } \\
\text { yönelik yapılan } \\
\text { çalışmaların dolaylı olarak } \\
\text { mesleki etik, bilgi beceri } \\
\text { ve mesleki tutum gibi } \\
\text { farklı açılardan faydal } \\
\text { olduğu yazarlar tarafından } \\
\text { tespit edilmiştir. }\end{array}$ \\
\hline 28 & $\begin{array}{l}\text { Muhasebe Meslek } \\
\text { Mensupları } \\
\text { KOBI'ler için } \\
\text { TFRS' ye Hazır mı? }\end{array}$ & $\begin{array}{l}\text { Ağca ve } \\
\text { Dalkılıç }\end{array}$ & 2014 & $\begin{array}{c}\text { Dumlupinar } \\
\text { Üniversitesi } \\
\text { Sosyal } \\
\text { Bilimler } \\
\text { Dergisi }\end{array}$ & $\begin{array}{l}\text { Kütahya ilinde TFRS ve } \\
\text { KOBİ TFRS nin } \\
\text { muhasebe meslek } \\
\text { mensupları tarafından } \\
\text { algılanma düzeyi ve } \\
\text { uygulanabilirliğinin } \\
\text { ölçümü amacıyla anket } \\
\text { uygulaması } \\
\text { gerçekleştirilmiştir. }\end{array}$ & $\begin{array}{l}\text { Kütahya' da faaliyet } \\
\text { gösteren } 66 \quad \text { meslek } \\
\text { mensubuna uygulanan } \\
\text { anketler sonucunda uzun } \\
\text { vadede standartlara uyum } \\
\text { sağlayabileceklerini, iş̧, artacağ } 1 \\
\text { yüklerinin } \\
\text { bulgusuna ulaş1lmiştır. } \\
\text { Diğer bulgu ise meslek } \\
\text { mensupları eğitimlerin } \\
\text { üniversiteler tarafindan } \\
\text { verilmesini } \\
\text { istememektedirler. }\end{array}$ \\
\hline 29 & $\begin{array}{l}\text { Muhasebe Meslek } \\
\text { Mensuplarının KOBİ } \\
\text { TFRS ve Tam Set } \\
\text { TFRS Hakkındaki } \\
\text { Bilgi Düzeyleri ve } \\
\text { Düşünceleri: } \\
\text { Elazığ'da Ampirik } \\
\text { Bir Çalışma }\end{array}$ & Kaya & 2015 & $\begin{array}{c}\text { The Jorunal } \\
\text { Of Academic } \\
\text { Social } \\
\text { Science } \\
\text { Studies }\end{array}$ & $\begin{array}{l}\text { Elazı̆̆ İlinde } 74 \\
\text { muhasebe } \\
\text { mensubuna meslek } \\
\text { yöntemi uygulanarak } \\
\text { KOBI TFRS ve tam set } \\
\text { TFRS hakkındaki bilgi } \\
\text { düzeyleri ölçülmesi } \\
\text { amaçlanmıştır. }\end{array}$ & $\begin{array}{l}\text { Çalışmanın sonucunda, } \\
\text { meslek mensupları KOBI } \\
\text { TFRS hakkında tam set } \\
\text { TFRS ye göre daha bilgili } \\
\text { oldukları ve eğitim } \\
\text { almalarına } \\
\text { çevrelerinden karşılık } \\
\text { aldıklarını belirtmişlerdir. }\end{array}$ \\
\hline 30 & $\begin{array}{l}\text { Finansal } \\
\text { Raporlamada } \\
\text { Standardizasyon ve } \\
\text { Muhasebe Meslek } \\
\text { Mensuplarını } \\
\text { Zorlayan Öğrenme } \\
\text { Sürecinin Bilinçli } \\
\text { Yetkinlik Öğrenme } \\
\text { Modeli Temelinde } \\
\text { İrdelenmesi }\end{array}$ & $\begin{array}{l}\text { Bayazitlı ve } \\
\text { Diğerleri }\end{array}$ & 2015 & $\begin{array}{l}\text { Muhasebe ve } \\
\text { Vergi } \\
\text { Uygulamalar1 } \\
\text { Dergisi }\end{array}$ & $\begin{array}{lr}\text { Çalışmada } & \text { muhasebe } \\
\text { meslek mensuplarının } \\
\text { finansal } & \text { raporlama } \\
\text { standartlarının } & 2015 \text { yıll } \\
\text { itibariyle } & \text { bilgi } \\
\text { düzeylerinin } & \text { hangi } \\
\text { seviyede } & \text { olduğunun } \\
\text { öğrenilmesi } & \\
\text { amaçlanmıştır. Ayrıca } \\
\text { öğrenme seviyesi ile } \\
\text { ilgili bilinçli yetkinlik } \\
\text { modeliyle } & \text { öğrenme } \\
\text { süreci incelenmiştir. }\end{array}$ & 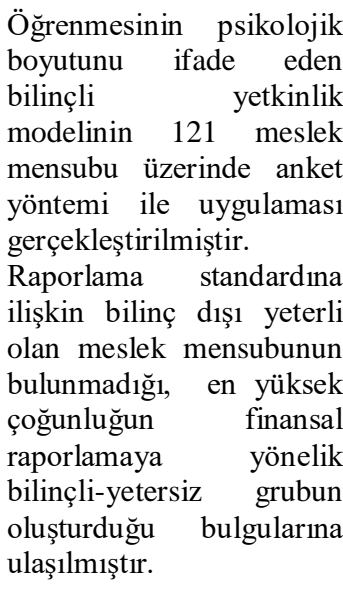 \\
\hline 31 & $\begin{array}{l}\text { Muhasebe Meslek } \\
\text { Mensuplarının KOBİ } \\
\text { TFRS Algılama ve } \\
\text { Uygulama Sürecine }\end{array}$ & $\begin{array}{l}\text { Şenol ve } \\
\text { Özçelik }\end{array}$ & 2015 & $\begin{array}{l}\text { Muhasebe } \\
\text { Bilim } \\
\text { Dünyası }\end{array}$ & $\begin{array}{lr}\text { Çalışmada Batı } & \text { Akdeniz } \\
\text { Bölgesinde } 246 & \text { meslek } \\
\text { mensubunun } & \text { KOBİ } \\
\text { TFRS' yi algılama }\end{array}$ & $\begin{array}{l}\text { Antalya, Burdur ve Isparta } \\
\text { illerinde gerçekleştirilmiş } \\
\text { olan bu çalışmada meslek } \\
\text { mensuplarının KOBI }\end{array}$ \\
\hline
\end{tabular}




\begin{tabular}{|c|c|c|c|c|c|c|}
\hline & $\begin{array}{lr}\text { Bakış } & \text { Açılarının } \\
\text { Tespiti Üzerine Bir } \\
\text { Araştırma: } \quad \text { Bat1 } \\
\text { Akdeniz } & \text { Bölgesi } \\
\text { Örneği } & \end{array}$ & & & Dergisi & $\begin{array}{l}\text { düzeyinin ölçülmesi } \\
\text { amaçlandığ1 } \\
\text { görülmektedir. }\end{array}$ & $\begin{array}{l}\text { TFRS } \\
\text { bilgilerinin yetersiz } \\
\text { olduğu, TMS/TFRS' ye } \\
\text { ilişkin bilgilerinin ise orta } \\
\text { düzeyde olduğu tespit } \\
\text { edilmiştir. }\end{array}$ \\
\hline 32 & $\begin{array}{l}\text { Muhasebe Meslek } \\
\text { Mensuplarının } \\
\text { UFRS Hakkındaki } \\
\text { Farkındalık } \\
\text { Düzeylerinin Tespiti: } \\
\text { Bolu İli Örneği }\end{array}$ & $\begin{array}{l}\text { Yel ve } \\
\text { Erdem }\end{array}$ & 2015 & $\begin{array}{l}\text { Ekonomik ve } \\
\text { Sosyal } \\
\text { Araştırmalar } \\
\text { Dergisi }\end{array}$ & $\begin{array}{l}\text { Bolu ilindeki SMMM } \\
\text { odasına kayıtlı aktif } \\
\text { olarak muhasebe meslek } \\
\text { sahiplerinin IFRS } \\
\text { farkındalık düzeylerinin } \\
\text { ölçülmesi amaçlanmıştır. }\end{array}$ & $\begin{array}{l}\text { Bolu ilinde } 93 \text { meslek } \\
\text { mensubuna uygulanan } \\
\text { anket sonucunda UFRS } \\
\text { farkındalık düzeylerinin } \\
\text { ve bilgi düzeylerinin } \\
\text { yüksek olduğu tespit } \\
\text { edilmiştir. }\end{array}$ \\
\hline 33 & $\begin{array}{l}\text { Muhasebe Meslek } \\
\text { Mensuplarının } \\
\text { Proaktif Kişilik } \\
\text { Özelliklerinin, } \\
\text { Kariyer } \\
\text { Memnuniyeti İle } \\
\text { UFRS' ye Bakş } \\
\text { Açıları ve Bilgi } \\
\text { Düzeyleri Üzerine } \\
\text { Etkisi }\end{array}$ & $\begin{array}{c}\text { Boyar ve } \\
\text { Güngörmüş }\end{array}$ & 2016 & $\begin{array}{l}\text { Muhasebe ve } \\
\text { Finansman } \\
\text { Dergisi }\end{array}$ & $\begin{array}{lr}\text { Proaktif } & \text { kişilik } \\
\text { özelliğine sahip } & \text { meslek } \\
\text { mensuplarının } & \text { kişilik } \\
\text { özelliğiyle } & \text { finansal } \\
\text { raporlama standartlarına } \\
\text { bakış açılarının ve bilgi } \\
\text { düzeylerinin } & \text { ilişkisi } \\
\text { incelenmesi } & \\
\text { amaçlanmıştır. } & \end{array}$ & $\begin{array}{l}175 \text { meslek mensubuna } \\
\text { yönelik anket uygulamas1 } \\
\text { Yapısal Eşitlik Modeli } \\
\text { kullanarak analiz } \\
\text { edilmiştir. Proaktif kişiliğe } \\
\text { sahip } \\
\text { mensuplarının } \\
\text { memnuniyet duriyer } \\
\text { yüksek olduğu ve } \\
\text { kariyerinden memnun olan } \\
\text { meslek mensuplarının } \\
\text { UFRS' ye bakıs açılarının } \\
\text { olumlu olduğu sonucuna } \\
\text { ulaşılmıştır. Proaktif } \\
\text { kişilik özelliğine sahip } \\
\text { meslek mensuplarının } \\
\text { UFRS bilgi düzeyi yüksek } \\
\text { olduğ tespit edilmiştir. }\end{array}$ \\
\hline
\end{tabular}

Yükseköğretim Kurulu Başkanlığı Ulusal Tez Merkezi'nde TFRS ile ilgili araştırma örneklemini muhasebe meslek mensuplarının oluşturduğu izinli lisansüstü tezler Tablo 2' deki şekilde listelenmiştir.

Tablo 2: TFRS/KOBİ TFRS’ nin Muhasebe Meslek Mensuplariyla Birlikte Yer Aldığı Lisansüstü Tezler

\begin{tabular}{|c|c|c|c|c|c|}
\hline No & Tez Adı & Yazarı & Yılı & Tez Türü & Bulgular \\
\hline 1 & $\begin{array}{l}\text { Türkiye Finansal Raporlama Standartları } \\
\text { (TFRS)' nın Varlıkları Değerlemesi } \\
\text { Hususunda Getirdiği Yenilikler: Serbest } \\
\text { Muhasebeci Mali Müşavirlerin Bilgi } \\
\text { Düzeylerinin Tespitine Yönelik Bir } \\
\text { Araştırma }\end{array}$ & Ercan Çelik & 2012 & Doktora & $\begin{array}{l}\text { Yazar tez uygulamasın } \\
\text { Türkiye genelinde faaliyet } \\
\text { gösteren } 396 \text { meslek } \\
\text { mensubuna anket yöntemiyle } \\
\text { gerçekleştirmiştir. Araştırma } \\
\text { sonucunda SMMM' lerin } \\
\text { yeterli bilgi sahibi } \\
\text { olmadıklarını tespit etmiştir. }\end{array}$ \\
\hline 2 & $\begin{array}{l}\text { Yeni TTK' nın / TFRS' nin Muhasebecilik } \\
\text { Mesleğine Getirmiş Olduğu Yenilikler İle } \\
\text { TFRS' nin Uygulanması Aşamasında Mali } \\
\text { Müşavirlerin Karşılaștığı Zorluklar, }\end{array}$ & $\begin{array}{l}\text { Mehmet Ali } \\
\text { Ünsal }\end{array}$ & 2014 & $\begin{array}{l}\text { Yüksek } \\
\text { Lisans }\end{array}$ & 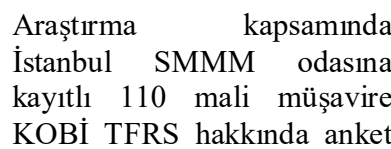 \\
\hline
\end{tabular}




\begin{tabular}{|c|c|c|c|c|c|}
\hline & $\begin{array}{l}\text { Belirsizlikler Ve Çözüm Önerileri: İstanbul } \\
\text { / Esenler Örneği }\end{array}$ & & & & \begin{tabular}{lr}
\multicolumn{3}{l}{ uygulanarak veri toplanmıştır. } \\
Sonuç olarak & mali \\
müşavirlerin KOBI & TFRS \\
hakkında & zorluk \\
yaşayacaklarına ulaşmıştır.
\end{tabular} \\
\hline 3 & $\begin{array}{l}\text { KOBİler İçin Uluslararası Finansal } \\
\text { Raporlama Standardının Muhasebe Meslek } \\
\text { Mensupları Açısından Farkındalığı (Muğla } \\
\text { İli Ve Çevresindeki Muhasebe Meslek } \\
\text { Mensupları Üzerine Bir Çalışma }\end{array}$ & Elif Ayhan & 2014 & $\begin{array}{l}\text { Yüksek } \\
\text { Lisans }\end{array}$ & $\begin{array}{l}\text { Yazar KOBI'ler için UFRS } \\
\text { uygulanabilirliğini } \\
\text { etmek amaciyla } 73 \text { tespit } \\
\text { mensubuna 5'li likert } \\
\text { ölçeğiyle hazırlamış oldukları } \\
\text { anketi uygulamışlardır. } \\
\text { KOBİ'lerde UFRS' lerin } \\
\text { etkin olabilmesi için gerekli } \\
\text { şartları sonuç bölümünde } \\
\text { yazar tarafından belirtilmiştir. }\end{array}$ \\
\hline 4 & $\begin{array}{l}\text { TFRS Çerçevesinde KOBİ Muhasebe } \\
\text { Standartlarının Muhasebe Meslek Grupları } \\
\text { Tarafindan Alg1 Düzeylerinin Tespitine } \\
\text { Yönelik Uygulama: Marmara Bölgesi } \\
\text { Örneği }\end{array}$ & Hasan Cinit & 2013 & $\begin{array}{l}\text { Yüksek } \\
\text { Lisans }\end{array}$ & $\begin{array}{l}\text { Yazar TFRS ve KOBİ TFRS } \\
\text { hakkındaki görüşlerini almak } \\
\text { amacıyla Marmara bölgesinde } \\
11 \text { ilde faaliyet gösteren } 950 \\
\text { meslek mensubuna, } 64 \text { adet } \\
\text { sorunun yer aldığ1 anket } \\
\text { uygulamasını yapmıştır. } \\
\text { Araştırma sonucunda yazar } \\
\text { meslek mensuplarının sürekli } \\
\text { eğitime tabi tutulmas } \\
\text { gerektiğini vurgulamıştır. }\end{array}$ \\
\hline 5 & $\begin{array}{l}\text { KOBİ TFRS Setinin Muhasebe Meslek } \\
\text { Mensupları Tarafından Uygulanabilirliği } \\
\text { Üzerine Bir Araştırma }\end{array}$ & Elçin Eren & 2012 & $\begin{array}{l}\text { Yüksek } \\
\text { Lisans }\end{array}$ & $\begin{array}{l}\text { Eren Kütahya ilinde } 66 \\
\text { meslek mensubuna KOBI } \\
\text { TFRS seti hakkındaki bilgi } \\
\text { düzeylerini ölçmek amacıyla } \\
\text { anket yöntemi uygulamıştır. } \\
\text { Araştırma kapsamında yer } \\
\text { alanları \%42,4'ünün KOBİ } \\
\text { TFRS hakkında yeterli bilgi } \\
\text { sahibi olduklarını tespit } \\
\text { etmişlerdir. }\end{array}$ \\
\hline 6 & $\begin{array}{l}\text { KOBİ' ler İçin UFRS Taslağının Edirne Ve } \\
\text { Kırklareli İllerindeki Muhasebe Meslek } \\
\text { Mensupları Tarafından Değerlendirilmesi }\end{array}$ & $\begin{array}{l}\text { Elçin } \\
\text { Bayraktaroğlu }\end{array}$ & 2012 & $\begin{array}{l}\text { Yüksek } \\
\text { Lisans }\end{array}$ & $\begin{array}{lr}\text { Edirne ve Kırklareli } & \text { illerinde } \\
\text { KOBİ UFRS taslağının nasıl } \\
\text { algılandığının } & \text { ölçümüne } \\
\text { yönelik } 115 & \text { meslek } \\
\text { mensubuna } & \text { anket } \\
\text { uygulanmıştır. Yazar } & \text { sonuç } \\
\text { olarak araştırma } & \text { konusu } \\
\text { hakkında } & \text { meslek } \\
\text { uygulayıcılarının } & \text { bilgi } \\
\text { eksikliği } & \text { olduğunu } \\
\text { belirtmiştir. } & \end{array}$ \\
\hline 7 & $\begin{array}{l}\text { KOBİler İçin UFRS' nin İncelenmesi Ve } \\
\text { Ülkemizdeki Muhaseber Mesleği } \\
\text { Mensupları Tarafından Benimsenme } \\
\text { Durumuna Yönelik Bir Araştırma: Mardin } \\
\text { Örneği }\end{array}$ & İlknur Babaoğlu & 2012 & $\begin{array}{l}\text { Yüksek } \\
\text { Lisans }\end{array}$ & $\begin{array}{lrr}\text { Mardin ilinde } 67 & \text { anketten } \\
\text { elde edilmiş } & \text { veriler } \\
\text { sonucunda, KOBİ } & \text { UFRS } \\
\text { hakkında farkındalığın yeterli } \\
\text { düzeyde rolmadığına } \\
\text { ulaşılmıştır. }\end{array}$ \\
\hline 8 & $\begin{array}{l}\text { KOBİ'ler İçin UFRS Taslağının Muhasebe } \\
\text { Mesleği } \quad \text { Mensupları } \quad \text { Tarafından }\end{array}$ & Sema Ülkü & 2008 & $\begin{array}{l}\text { Yüksek } \\
\text { Lisans }\end{array}$ & $\begin{array}{l}\text { Yazar KOBİ UFRS taslağının } \\
\text { meslek mensupları açısından }\end{array}$ \\
\hline
\end{tabular}




\begin{tabular}{|c|c|c|c|c|c|}
\hline & $\begin{array}{l}\text { Algılanışına Yönelik } \quad \text { Bir } \quad \text { Araştırma } \\
\text { (İstanbul Örneği) }\end{array}$ & & & & $\begin{array}{l}\text { alg1 düzeyini } r \text { ölçmek } \\
\text { amaciyla İstanbul } \\
\text { araştırma yapmıştır. } \\
\text { meslek mensubuna anket } \\
\text { uygulanması sonucunda } \\
\text { eğitimlerin sürekli olmas1 } \\
\text { gerektiği vurgulanmıştır. }\end{array}$ \\
\hline 9 & $\begin{array}{lr}\text { Türkiye } & \text { Finansal } \\
\text { Raporlama Standartlarının } & \text { Finansal } \\
\text { Tablolar Üzerine Etkileri Ve Göller } \\
\text { Yöresindeki Kobilerde Muhasebeden } \\
\text { Sorumlu Yöneticiler Üzerine Bir Araştırma }\end{array}$ & Ozan Özdemir & 2007 & $\begin{array}{l}\text { Yüksek } \\
\text { Lisans }\end{array}$ & $\begin{array}{lr}\text { Yazar Isparta } & \text { ve Burdur } \\
\text { illerindeki } & \text { KOBI'lerdeki } \\
\text { muhasebe } & \text { sorumlu } \\
\text { yöneticilerinin } & \text { TFRS' nin } \\
\text { mali tablolar üzerindeki } \\
\text { etkileri hakkındaki bilgi ve } \\
\text { düşüncelerini } & \text { ölçmeye } \\
\text { yönelik araştırma } & \text { yapmıştır. } \\
\text { Araştırma kapsamındaki } 39 \\
\text { işletmedeki } & \text { sorumlu } \\
\text { yöneticilere } & \text { anket } \\
\text { uygulanması sonucunda, konu } \\
\text { hakkında bilgi } & \text { eksikliğinin } \\
\text { var olduğu } & \text { bulgusuna } \\
\text { ulaşılmıştır. } & \end{array}$ \\
\hline
\end{tabular}

Tablo 2' deki tezler incelendiğinde 1 adet doktora tezi ve 8 adet yüksek lisans tezi olmak üzere toplam 9 adet lisansüstü tez mevcuttur. Tez yazarlarının aynı zamanda aynı konuyla ilgili makaleleri Tablo 1' de yer almaktadır.

\subsection{Türkiye Finansal Raporlama Standartlarıyla Yapılmış Olan Çalışmaların Değerlendirilmesi}

Bugüne kadar farklı illerde ve bölgelerde yapılmış olan çalışmaların bulguları doğrultusunda, muhasebe standartlarının uygulamasının zorunlu hale gelmesinden bu yana Tablo 1 ve Tablo 2'deki çalışmaların incelenmesiyle çıkarılan ortak sonuçlar aşağıdaki şekilde özetlenebilir:

- Ankara, İstanbul, Çankırı, Trabzon, Ordu, Kahramanmaraş, Eskişehir, Samsun, Niğde, Elazığ, Erzincan, Erzurum, Malatya, Afyon, Denizli, Uşak, Kütahya, Burdur, Isparta, Bolu, Çanakkale, Balıkesir, Bursa, Edirne, Kırklareli, Tekirdağ, Amasya, Çorum, Antalya, Alanya, Mardin illerinde muhasebe meslek mensuplarına yönelik olarak uygulama yapıldığı,

- Araştırma kapsamındaki bazı çalışmalar farklı yıllarda olmak üzere aynı birden fazla uygulama yapılmıştır. Aynı illerdeki yapılan çalışmalarda bilgi eksikliği sonucu değişmediği,

- Fidan ve Cinit tarafından muhasebe meslek mensuplarına yönelik olarak TFRS ile ilgili olarak farklı illerde 3 makalenin ve danışmanlığını Fidan' nın yürüttüğü Hasan Cinit tarafından yazılan 1 adet yüksek lisans tezi yer aldığ1,

- Akademik çalışmalardaki araştırma yöntemi açısından çoğunlukla anket yöntemi tercih edildiği,

- Tablo 1 ve tablo 2' ye göre TFRS ve KOBİ TFRS hakkındaki ulaşılan bilimsel çalışmaların ilki 2007 yılında ve son çalışmanın 2016 yılında yapılmış olduğu,

- Muhasebe meslek mensuplarının muhasebe standartları hakkında bilgi düzeyi yetersizliğinin söz konusu olduğu, 
- Ankara ilinde gerçekleştirilen araştırmalarda; Can ve Gör (2011) tarafindan yapılan çalışma bulgusu olarak TFRS ile ilgili meslek mensuplarının bilgi düzeyi yeterli tespit edilmişken, Özdemir (2012) tarafından bulunan sonuç TFRS ile ilgili meslek mensuplarının bilgi düzeyi yetersiz olarak tespit edilmiştir. Gerçekleştirilmiş olan iki çalışmada zit bulgular olduğu görülmektedir.

- İlgili kurumlar tarafından sürekli sistematik eğitim olması gerektiği ve eğitim kalitesinin artırılıp öğretici modellerde desteklenmesi,

- Bazı çalışmalarda muhasebe standartlarının uygulanması nedeniyle meslek birakma eğilimi olduğu,

- Meslekte genel anlamda fazladan iş yükü doğuracağ1,

- Meslek mensuplarında kaygı, stres gibi olumsuz psikolojik bask1 oluştuğu,

- Uluslararası yatırımlarda olumlu sonuçlar doğuracağını,

- Finansal tablolarda daha şeffaf, gerçekçi, doğru raporlama oluşturacağg

- Standartların çeviri sorununun söz konusu olması

Araştırma amacına yönelik olarak 33 makale ve 9 lisansüstü tez incelenmiştir. Muhasebe meslek mensuplarına yönelik olarak yapılmış olan TFRS ve KOBİ TFRS hakkındaki bilimsel çalışmaların en önemli ortak bulgusunun TFRS ve KOBİ TFRS hakkındaki bilgi eksikliğinin var olduğu dikkat çekmektedir.

\section{SONUÇ VE ÖNERILER}

Uluslararası Finansal Raporlama Standartları'nın çevirisi olan Türkiye Finansal Raporlama Standartları (TFRS) 1 Ocak 2013 tarihi itibariyle tüm şirketlerde uygulama zorunluluğu getirilmiştir. Bu kapsamda muhasebe meslek mensupları uygulamada önemli rol oynamaktadırlar. Araştırmacılar TFRS ‘ nin muhasebe meslek mensupları tarafindan uygulanmasına yönelik görüşleri, bilgi düzeyleri, beklentileri gibi açılardan farklı illerde çalışmalar yapmışlardır.

Muhasebe standartlarıyla ilgili bugüne kadar yapılan akademik çalışmaların bolluğu, verilen eğitimler düşünüldüğünde ve uygulama zorunluluğu getirilmiş olmasına rağmen hala standartlarla ilgili bilgi düzeyi ve eğitim eksikliği olması bir paradoks oluşturmaktadır. $\mathrm{Bu}$ nedenle zorunluluk getirilmiş muhasebe standartlarıyla ilgili eğitimlerin niteliği tartış1labilir hale gelmektedir. Verilecek eğitimler öncesinde ve sonrasında bu durumun ölçülmesi için akademik anlamda ön test-son test uygulanarak meslek uygulayıcılarının öğrenim düzeyi ve eğitimlerin amacına ulaşıp ulaşmadığı öğrenilmelidir. Muhasebe standartlarıyla ilgili olan eğitimler bilimsel öğretici modellerle desteklenmelidir.

Muhasebe standartlarının uygulama zorunluluğuyla birlikte standartların oluşturulma amacı doğrultusunda olumlu sonuçlar elde edilmesi hedeflenmiştir. Muhasebe standartlarının amacına ulaşabilmesi için, muhasebe ve finans alanında mesleğini icra etmek isteyen öğrenciler açısından muhasebe standartları meslek liselerinde ve üniversitelerin ilgili bölümlerinde eğitim müfredatında yer alması gerekliliği açık bir şekilde ortadadır.

TFRS' nin olumsuz sonuçları; bilgi düzeyi eksikliği, sistematik eğitim sorunu, standartların çeviri sorunu, meslek mensupları açısından fazladan iş yükü, meslek bırakma eğilimi düşüncesine, stres ve kaygıya yol açmaktadır. Olumlu açıdan daha şeffaf, gerçekçi ve doğru finansal raporlar olacağ 1 , vergi muhasebeciliğinin bilgi muhasebeciliğine dönüşeceği, yeni meslek mensuplarının standartlarla ilgili bilgi düzeyi ve farkındalığının yüksek olduğu sonuçlarına ulaşılmıştır. Muhasebe standartlarının kabul edilmesi ve yürürlüğe girme tarihi düşünüldüğünde bu konuyla ilgili yapılacak olan makalelerin TFRS farkındalığ ${ }_{1}$ ölçmesinin 
anlamsız olacağı ortadadır. Bunun yerine TFRS ile ilgili öğrenme ve uzmanlaşma süreciyle ilgili olumsuz sonuçların minimuma indirilebilecek bilimsel çalışmalar yapılmasının faydalı olacağı düşüncesindeyiz.

Standartların kanunen uygulama zorunluluğu getirilmiş olmasının yeterli ve verimli sonuçlarının olmadığı, bu nedenle ilk olarak TFRS' ye yönelik sürekli ve sistemli bir eğitimin olması gerektiği alanda yapılmış olan çalışmaların incelemesinin önemli bir çıktısıdır. Yapılmış olan benzer çalışmaların bulguları doğrultusunda bilgi ve eğitim eksikliğinin halen devam ettiği ise somut bir göstergedir. TFRS ve KOBİ TFRS ile ilgili olumsuz durumların önlenebilmesi için meslek odalarının sistemli ve akademisyenlerle işbirliği içerisinde çalışmalarını gerçekleştirmelidirler.

\section{KAYNAKÇA}

Abdioğlu, H., Kılıç, B.İ., Yavuz, S. ve Kuş, T. (2014). Muhasebe Standartlarının Uygulanma Sürecinde Muhasebe Meslek Mensuplarının Standartlara Bakış Açılarının ve Mesleki Yetkinliklerinin İncelenmesi Üzerine Balıkesir İlinde Bir Araştırma. Eskişehir Osmangazi Üniversitesi İ̈BF Dergisi, 9(3), 207-231.

Aktürk, A ve Akcanlı, F. (2013). Muhasebe Akademisyenlerinin Muhasebe Standartlarına Bakış Açıları ve Farkındalıkları Üzerine Bir Araştırma. Muhasebe Bilim Dünyası Dergisi, 1(4), 21-43.

Aktürk, A. (2014). Muhasebe Meslek Mensuplarının Muhasebe Standartlarına Uyumu Sürecinde Eğitim Faktörü Üzerine Antalya İlinde Bir Araştırma. Mali Çözüm Dergisi, 2(122), 63-84.

Ağca, A. ve Dalkılıç, E. (2014). Muhasebe Meslek Mensupları KOBİ'ler için TFRS' ye Hazır mı ?. Dumlupınar Üniversitesi Sosyal Bilimler Dergisi, 39, 1-20.

Apak, İ., Duman, H., Özpeynirci, R. ve Karakışla, E. (2016). Türkiye'de Muhasebe Eğitimi: Türkiye Muhasebe Eğitimi Sempozyumu Örneği. Internatinal Journal Of Human Sciences, 13(1), 169-197.

Arsoy, A. P. ve Bora, T. (2012). KOBI Muhasebe Standartlarının Gelişimi ve Türkiye Üzerine Bir Araştırma. Muhasebe ve Finansman Dergisi, 4(56), 17-27.

Ayhan, E. (2014). KOBI'ler İçin Uluslararası Finansal Raporlama Standardının Muhasebe Meslek Mensupları Açısından Farkındalı̆̆ı (Muğla İli Ve Çevresindeki Muhasebe Meslek Mensupları Üzerine Bir Çalışma, Yüksek Lisans Tezi, Adnan Menderes Üniversitesi, Aydın.

Babaoğlu, İ. (2012). KOBİ'ler Iç̧in UFRS' nin İncelenmesi Ve Ülkemizdeki Muhasebe Mesleği Mensupları Tarafindan Benimsenme Durumuna Yönelik Bir Araştırma: Mardin Örneği, Yüksek Lisans Tezi, Atatürk Üniversitesi, Erzurum.

Bayazitlı, E., Özdemir, F. S. ve Alpay, E. E. (2015). Finansal Raporlamada Standardizasyon ve Muhasebe Meslek Mensuplarını Zorlayan Öğrenme Sürecinin Bilinçli Yetkinlik Öğrenme Modeli Temelinde İrdelenmesi. Muhasebe ve Vergi Uygulamaları Dergisi, 8(1), 1-31.

Bayraktaroğlu, E. (2012). KOBI' ler İçin UFRS Taslağının Edirne Ve Kırklareli İllerindeki Muhasebe Meslek Mensupları Tarafindan Değerlendirilmesi, Yüksek Lisans Tezi, Trakya Üniversitesi, Edirne.

Bengü, H., Özdemir, F. S. ve Çelik, S. (2014). Niğde İlindeki Muhasebe Meslek Mensuplarının Finansal Raporlama Standartlarına Bakış Açılarının Ampirik Olarak Değerlendirilmesi. Niğde Üniversitesi İIBF Dergisi, 7(1), 175-203

Boyar, E. ve Güngörmüş, A. H. (2016). Muhasebe Meslek Mensuplarının Proaktif Kişilik Özelliklerinin, Kariyer Memnuniyeti İle UFRS' ye Bakış Açıları ve Bilgi Düzeyleri Üzerine Etkisi. Muhasebe ve Finansman Dergisi, 2(70), $55-66$.

Bozdemir, E. (2012). Yeni Türk Ticaret Kanunu'nun Muhasebe Meslek Mensupları Açısından Değerlendirilmesine Yönelik Ampirik Bir Çalışma. Muhasebe ve Finansman Dergisi, 2(54), 101-122. 
Can, İ. ve Gör, Y. (2011). Türkiye Finansal Raporlama Standartlarının Meslek Mensupları arasındaki Bilinirlik Düzeyini Ölçmeye Yönelik Bir Araştırma (Ankara ve Çankırı İlleri Örneği). World Of IFRS Dergisi, 2(5), 1-13.

Cengiz, H. (2014). Effects On International Financial Reporting Standards Application On Financial Ratios In Turkey. Int. Journal Of Management Economics and Business, 10(21), 163-177.

Christensen, H.B., Lee, E., ve Zeng, C. (2015). Incentives Or Standarts: What Determines Accounting Quality Changes Around IFRS Adoption?. European Accouinting Review, 24(1), 31-61.

Cinit, H. (2013). TFRS Çerçevesinde KOBİ Muhasebe Standartlarının Muhasebe Meslek Grupları Tarafindan Algı Düzeylerinin Tespitine Yönelik Uygulama: Marmara Bölgesi Örneği, Yüksek Lisans Tezi, Bilecik Şeyh Edebali Üniversitesi, Bilecik.

Çankaya, F. ve Hatipoğlu, O. (2011). Türkiye'de Uluslararası Muhasebe Standartları'nın Uygulanabilirliğini Etkileyen Faktörlerin Meslek Mensuplarınca Değerlendirilmesine Yönelik Bir Araştırma. Uluslararası İktisadi ve İdari Incelemeler Dergisi, 2(7), 61-88.

Çelik, E. (2014). Türkiye Finansal Raporlama Standartları (TFRS)' nın Varlıkların Değerlemesi Hususunda Getirdiği Yenilikler: Serbest Muhasebeci Mali Müşavirlerin Bilgi Düzeylerinin Tespitine Yönelik Bir Araştırma, Doktora Tezi, Çukurova Üniversitesi, Adana

Dabbağoğlu, K. ve Can, G. (2011). Serbest Muhasebeci ve Mali Müşavirlerin Yeni Türk Ticaret Kanunu ve Türkiye Finansal Raporlama Standartları Farkındalığı: Marmara Bölgesi Örneği. Anadolu Bil Meslek Yüksekokulu Dergisi, 24, $42-49$.

Dinç, E. ve Atabay, E. (2011). Muhasebe Meslek Mensuplarının TFRS' ye Yönelik Bir Araştırma - Trabzon Alt Bölgesi Örneği. World Of IFRS Dergisi, 5, 1-13.

Elitaş, C., Karakoç, M. ve Özdemir, F.S. (2011) Muhasebe Meslek Mensupları Perspektifinden Türkiye Muhasebe Standartlar1. World Of IFRS Dergisi, 5, 1-13.

Erdoğan, M. ve Dinç, E. (2009). Türkiye Muhasebe Standartları v Muhasebe Meslek Mensuplarının Bilgi Düzeylerinin İncelenmesi. Muhasebe ve Finansman Dergisi, 3(439, 154-169.

Eren, E. (2012). KOBI TFRS Setinin Muhasebe Meslek Mensuplarl Tarafindan Uygulanabilirliği Üzerine Bir Araştırma, Yüksek Lisans Tezi, Dumlupınar Üniversitesi, Kütahya.

Erol, M., Atmaca, M. ve Öztürk, S. (2011). Muhasebe Meslek Mensuplarının Türkiye Muhasebe ve Finansal Raporlama Standartlarına Bakış Açılarının Ölçülmesine İlişkin Ampirik Bir Çalışma. Muhasebe Öğretim Üyeleri ve Bilimsel Dayanı̧ma Vakfi Dergisi, 3, 225-267.

Fidan, M. E. ve Cinit, H. (2013). 1 Ocak 2013 Öncesinde Türkiye Finansal Raporlama Standartları Çerçevesinde KOBİ Muhasebe Standartlarının Muhasebe Meslek Mensupları Tarafından Algısı (Bursa İli Örneği). Muhasebe ve Denetime Bakış, 40, 63-82.

Fidan, M. E. ve Cinit, H. (2013). Türkiye Finansal Raporlama Standartları Çerçevesinde KOBİ Muhasebe Standartlarının Muhasebe Meslek Mensupları Tarafından Algı Düzeylerinin Tespitine Yönelik Uygulama (Eskişehir İli Örneği). Muhasebe ve Finansman Dergisi, 3(59), 39-60.

Fidan, M. E. ve Cinit, H. (2014). Muhasebe Meslek Mensuplarının Eğitim Düzeyleri İle Muhasebe Standartlarına Yönelik Algıları Arasındaki İlişki Üzerine Bir Araştırma: Marmara Bölgesi Örneği. KMÜ Sosyal ve Ekonomik Araştırmalar Dergisi, 3(26), 72-85.

Gökgöz, A. (2012). KOBİ TFRS Çerçevesinde Stokların Muhasebeleştirilmesi. Afyon Kocatepe Üniversitesi İ̈BF Dergisi, 14(2), 243-258.

Gönen, S. ve Demir, Ç. (2012). Vergi Usul Kanunu ve KOBİ TFRS Bölüm 13 Açısından Stokların Karşıslaştırılması. Uluslararası Alanya İşletme Fakültesi Dergisi, 4(2), 163-171. 
Optimum Journal of Economics and Management Sciences, Vo1. 4, No. 1- http://dergipark.ulakbim.gov.tr/usakoeyb/ Akyüz and Yeşil - IFRS of the Accounting Profession in Terms of Evaluation of the Academic Studies that Have Been Made against Members

Güneş, R., Durmuş, A. F. ve Solak, B. (2011). Muhasebe Meslek Mensuplarının KOBİ TFRS' ye Yönelik Bilgi Düzeyleri ve Uygulamaya Yönelik Beklentileri: Elazığ ve Malatya İlleri Örneği. World Of IFRS Dergisi, 5, 1-14.

Hacıhasanoğlu, T., Karaca, N. ve Demirci, Ş. D. (2012). KOBİ'ler için TFRS' nin Getirdiği Yenilikler ve Uygulanabilirliği Üzerine Ankara İlinde Bir Araştırma. World Of IFRS Dergisi, 4, 1-22.

Hatunoğlu, Z., Uçaktürk, M. ve Kıllı, M. (2013). Türkiye Finansal Raporlama Standartları'nın Bilinirlik Düzeyi Üzerine Kahramanmaraş’ta Bir Alan Çalışması. Niğde Üniversitesi İ̈BF Dergisi, 6(1), 51-62.

Hussain, F.F., Chand, P.V, ve Rani, P. (2012). The Impact Of IFRS For SMEs On The Accounting Profession: Evidence From Fiji. Accounting and Taxation, 4(2), 107-118.

International Accounting Standards Board IASB. Uluslararası Finansal Raporlama Standartları (IFRS). 5 Ekim 2016 tarihinde http://www.ifrs.org/About-us/IASB/Pages/Home.aspx adresinden erişildi.

Kamu Gözetimi, Muhasebe ve Denetim Standartları Kurumu, TMS/TFRS $2016 \quad$ Seti. http://www.kgk.gov.tr/content_detail-345-2310-tms-tfrs-2016-seti.html, (01.10.2016).

Kaya, G. A. (2015). Muhasebe Meslek Mensuplarının KOBİ TFRS ve Tam Set TFRS Hakkındaki Bilgi Düzeyleri ve Düşünceleri: Elazığ’ da Ampirik Bir Çalışma. The Jorunal Of Academic Social Science Studies, 36, 157-178

Köroğlu, Ç. ve Doğan, C. (2012). Uluslararası Finansal Raporlama Standartlarına Uyum Süreci ve Muhasebe Meslek Mensuplarının Bilgi Düzeylerinin İncelenmesi (Marmaris İlçesi Örneği). World Of IFRS Dergisi, 5, 1-14.

Kurcan, F., Uyar, S. ve Tetik, N. (2011). Meslek Mensuplarının UFRS' ye Bakış Açıları ve Farkındalık Düzeyleri Üzerine Bir Araştırma. Muhasebe ve Vergi Uygulamaları Dergisi, 4(3), 15-28.

Kurtçu, E. ve Akdoğan, H. (2011). KOBİ'lerde UFRS Uygulamalarının Denetim Üzerine Olası Etkilerini Görmek Amacıyla Serbest Muhasebeci ve Mali Müşavir İle Yeminli Mali Müşavirler Üzerine Bir Araştırma. Hitit Üniversitesi Sosyal Bilimler Enstitüsü Dergisi, 4(2), 63-85.

Kamu Gözetimi, Muhasebe ve Denetim Standartlar1 Kurumu. Küçük ve Orta Büyüklükte Isşletmeler İçin Türkiye Finansal Raporlama Standartları'nın (KOBI TFRS). http://www.kgk.gov.tr/contents/files/KOBI_TFRS.pdf, (05.10.2016).

Özdemir, F. S. (2012). KOBILLER İçin Finansal Raporlama Standardı ve Mali Müşavirlerin Uygulama Öncesi İlgi Düzeylerine Yönelik Ampirik Bir Araştırma. Muhasebe ve Denetime Bakış, 38, 57-84.

Özdemir, F. S. (2013). Finansal Raporlama Standartlarını Öğrenme Sürecinde Serbest Muhasebeci Mali Müşavirlerin Durumları: Samsun'da Ampirik Bir Araștırma. Muhasebe ve Denetime Bakış, 41, 81-108.

Özdemir, O. (2007). Türkiye Finansal Raporlama Standartlarının Finansal Tablolar Üzerine Etkileri Ve Göller Yöresindeki Kobilerde Muhasebeden Sorumlu Yöneticiler Üzerine Bir Araştırma, Yüksek Lisans Tezi, Süleyman Demirel Üniversitesi, Isparta.

Şenol, H. ve Özçelik, H. (2015). Muhasebe Meslek Mensuplarının KOBİ TFRS Algılama ve Uygulama Sürecine Bakış Açılarının Tespiti Üzerine Bir Araştırma: Batı Akdeniz Bölgesi Örneği. Muhasebe Bilim Dünyası Dergisi, 17, 871-891.

Ülkü, S. (2008). KOBİler İçin UFRS Taslağının Muhasebe Mesleği Mensupları Tarafindan Algılanışına Yönelik Bir Araştırma (İstanbul Örneği), Yüksek Lisans Tezi, Sakarya Üniversitesi, Sakarya.

Ünsal, M. A. (2014). Yeni TTK' nın / TFRS' nin Muhasebecilik Mesleğine Getirmiş Olduğu Yenilikler İle TFRS' nin Uygulanması Aşamasında Mali Müşavirlerin Karşılaştı̆̆ Zorluklar, Belirsizlikler Ve Çözüm Önerileri: İstanbul / Esenler Örneği, Yüksek Lisans Tezi, Marmara Üniversitesi, İstanbul.

Yel, T. A. ve Çiftçi, D. Ö. (2013). Yeni Türk Ticaret Kanunu İle TFR/TMS Konusunda Getirilen Yenilikler ve Ordu İli Muhasebe Meslek Mensuplarının Bakış Açılarını Değerlendirmeye Yönelik Bir Uygulama. Muhasebe ve Vergi Uygulamaları Dergisi, 6(2), 93-117. 
Yel, T. A. ve Erdem, M. S. (2015). Muhasebe Meslek Mensuplarının UFRS Hakkındaki Farkındalık Düzeylerinin Tespiti: Bolu İli Örneği. Ekonomik ve Sosyal Araştırmalar Dergisi, 11(2), 217-231.

Yıldırım, S. (2012). Muhasebe Meslek Mensuplarının TTK, TMS/TFRS ve KOBI TFRS İle İlgili Genel Görüşleri: Erzincan Örneği. Erzincan Üniversitesi Sosyal Bilimler Enstitüsü Dergisi, 5(2), 403-416.

Yılmaz, Z., Şahin, Z. ve Çankaya, F. (2014). Orta ve Doğu Karadeniz Bölgesindeki Öğrenci, Akademisyen ve Uygulayıcıların TMS/TFRS Farkındalıkları ve Görüşleri Üzerine Bir Çalışma. Muhasebe Bilim Dünyası Dergisi, $16(2), 109-135$.

Yücel, S., Öncü, M. A. ve Kartal, O. (2015). Türkiye'de Muhasebe ve Finansal Raporlama Standartları Konularında Yayınlanmış Akademik Çalışmalar (2007-2014 Arası Literatür Taraması). Muhasebe ve Finansman Dergisi, 4(68), $39-66$. 